\title{
Сборник поучений «Ключ разума» из фондов Национального музея Тувы"
}

\author{
Евгений В. Бембеев, Баазр А. Бичеев \\ Калмыцкий научный центр Российской академии наук, Российская Федерация, \\ Каадыр-оол А. Бичелдей \\ Национальный музей им. Алдан-Маадыр Республики Тыва, Российская Федерация
}
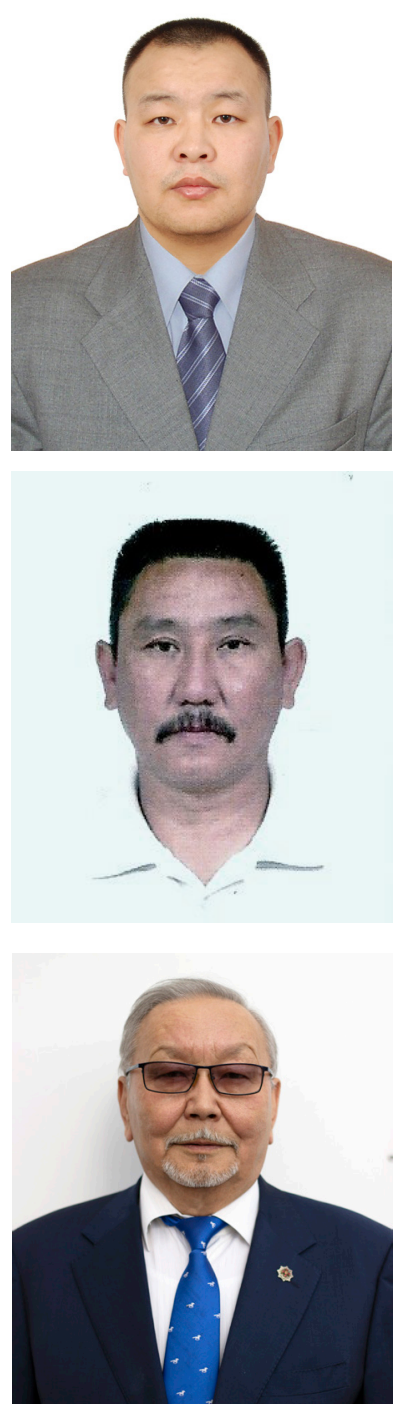

Исследование проведено в рамках государственной субсидии - проект «Устное и письменное наследие монгольских народов России, Монголии и Китая: трансграничные традиции и взаимодействия» (регистрационный номер АААA-А19-119011490036-1).

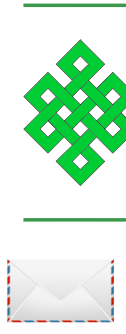

Для цитирования:

Бембеев Е. В., Бичеев Б. А., Бичелдей К. А. Сборник поучений «Ключ разума» из фондов Национального музея Тувы [Электронный ресурс] // Новые исследования Тувы. 2019, № 3. URL: https://nit.tuva.asia/nit/article/view/873 (дата обращения: дд.мм. гг.). DOI: 10.25178/nit.2019.3.14

Бембеев Евгений Владимирович - кандидат филологических наук, старший научный сотрудник отдела монгольской филологии Калмыцкого научного центра Российской академии наук. Адрес: 358000, Россия, г. Элиста, ул. И. К. Илишкина, д. 8. Тел.: +7 (84722) 3-55-06. Эл. адрес: galdma@yandex.ru ORCID ID: 0000-0001-9936-221X

Бичеев Баазр Александрович - доктор филологических наук, ведущий научный сотрудник отдела монгольской филологии Калмыцкого научного центра Российской академии наук. Адрес: 358000, Россия, г. Элиста, ул. И. К. Илишкина, д. 8. Тел.: +7 (84722) 3-55-06. Эл. адрес: baazr@mail.ruＯRCID ID:0000-0002-9352-7367

Бичелдей Кадыр-оол Алексеевич - доктор филологических наук, профессор, директор Национального музея им. Алдан-Маадыр Республики Тыва. Адрес: 667000, Россия, г. Кызыл, ул. Титова, д. 30. Тел.: +7 (39422) 2-28-04. Эл. ад-рес: tuva-museum@ mail.ru ORCID ID: 0000-0002-6754-7794

Bembeev Evegeny Vladimirovich, Candidate of Philology, Senior Research Fellow, Department of Mongolian Philology, Kalmyk Research Center of the Russian Academy of Sciences. Postal address: 8 Ilishkin St., Elista 358000 Russian Federation. Tel.: +7 (84722) 3-55-06. E-mail: galdma@yandex.ru

Bicheev Baazr Aleksandrovich, Doctor of Philology, Leading Research Fellow, Department of Mongolian Philology, Kalmyk Research Center of the Russian Academy of Sciences. Postal address: 8 Ilishkin St., Elista 358000 Russian Federation. Tel.: +7 (84722) 3-55-06. E-mail:baazr@mail.ru

Bicheldei Kadyr-ool Alekseevich, Doctor of Philology, Professor, Director, Aldan-Maadyr National Museum of the Republic of Tuva. Postal address: 30 Titov St., Kyzyl 667000 Russian Federation. Tel.: +7 (39422) 2-28-04. E-mail: tuva-museum@mail.ru 


\title{
"The Key to Wisdom": A collection of teachings from the funds of the National Museum of Tuva"
}

\author{
Evgenyi V. Bembeev, Baazr A. Bicheev \\ Kalmyk Research Center of the Russian Academy of Sciences, Russian Federation \\ Kaadyr-ool A. Bicheldei \\ Aldan-Maadyr National Museum of Republic of Tuva, Russian Federation
}

\begin{abstract}
The article introduces the text of the Oirat manuscript "The Key to Wisdom", preserved among the collections of the AlanMaadyr National Museum of the Republic of Tuva. "The Key to Wisdom" is an original composition of old Mongolian literature in the genre of teachings or instructions (surgaal). According to the established tradition of ascribing the authorship of works of literature to outstanding people, the manuscript lists Genghis Khan as its author. Structurally the work is divided in either two or three parts. The first part supposedly contains the teachings of Genghis Khan, the second (and third) include Buddhist interpolations - moralizing stories from the "Subhashita" collection of teachings, well-known in the Buddhist world, and Nagarjuna's "The drop that feeds people".

The copy of "The Key to Wisdom" published here contains only the first part of the work, which ends with the wish that "the shastra by Genghis Khan will contribute to the prosperous existence of the state'. The text is written in Oirat 'clear writing', with the elements of the old Mongolian written language. Some phonetic features indicate that the text has been also influenced by colloquial language, but this impact was insignificant. The article provides a transliteration of the Oirat text with a parallel translation into Russian and commentary.
\end{abstract}

Keywords: collection of teachings; 'clear writing'; manuscript; Oirat language; Genghis Khan; old Mongolian written literature; Buddhist literature; translation, transliteration; National Museum of Tuva

"The study was carried out within the framework of state subsidies - the project "Oral and Written Heritage of the Mongolian Peoples of Russia, Mongolia and China: Cross-Border Traditions and Interactions" (registration number AAAA-A19-119011490036-1).

\section{For citation:}

Bembeev E. V., Bicheev B. A. and Bicheldey K. A. "The Key to Wisdom": A collection of teachings from the funds of the National Museum of Tuva. The New Research of Tuva. 2019, № 3. URL: https://nit.tuva.asia/nit/article/view/873 (access date ...). DOI: 10.25178/nit.2019.3.14

В фондах Национального музея им. Алдан-Маадыр Республики Тыва (далее - НM РТ) хранится большая коллекция монгольских рукописей и ксилографов, насчитывающая более 900 единиц хранения. Известный российский монголовед А. Г. Сазыкин (1943-2005), описывая эту коллекцию, отмечал, что по состоянию на 1985 г. она насчитывает 938 единиц хранения, из которых восемь рукописей тексты, написанные ойратским «ясным письмом» (Сазыкин, 1992).

Наличие на территории Тувы монгольских рукописей не вызывает вопросов, поскольку постоянные культурно-экономические связи этого региона с Монголией общеизвестны. Скорее удивляет наличие столь малого количества текстов на «ясном письме», которое широко бытовало у ойратов Западной Монголии, граничащей с Тувой. Именно оттуда была в свое время доставлена Б. Я. Владимирцовым основная часть рукописей на «ясном письме», хранящихся сегодня в фондах Института восточных рукописей РАН и в отделе по направлению Востоковедение Научной библиотеки им. М. Горького СПбГУ (Сазыкин, 1986; Сазыкин, 1988: 14).

Среди ойратской части собрания монгольских рукописей имеется сборник поучений, приписываемых Чингис-хану. Он известен монголоведам под названием «Ключ разума» («Oyouni tülküür»). В каталоге монгольских рукописей и ксилографов НМ РТ этот текст значится под шифром M-658 (Sazykin, 1994: 370).

M-658. Oyouni tülküür kemēkü sudūr orošiboi (л. 1a); oyouni tülküür nertē sudur öüni suraqtun: kereqteibui: üligerinu jügürtei xān: xānkarudi-bēr (л. 1b).

Ойр. рук., лл. 1-11 (нет конца), 22 х 8.5, 22 стк., бумага желтого цвета, красная и черная тушь, калам. 


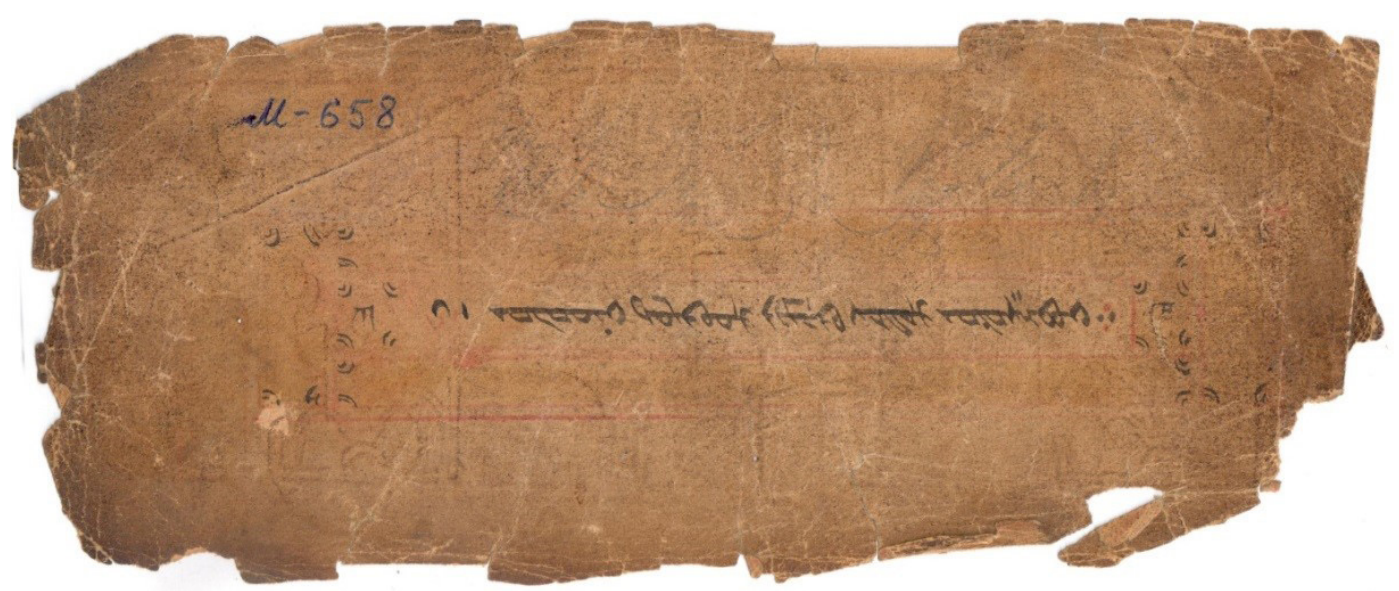

Фото 1. Титульный лист 1а. рукописи «Оуоuпi tülkü̈̈r keте̄kü sudūr orošiboi» (из фонда Национального музея им. Алдан-Маадыр Республики Тыва)

Photo 1. Title page 1a of the manuscript «Oyouni tülküür kemēkü sudūr orošiboi» (from the collections of the Aldan-Maadyr National Museum of the Republic of Tuva)

Рукопись написана каллиграфическим почерком. Края листов сильно изношены. Название на титульном листе обрамлено двойной рамкой красного цвета. На оборотной стороне титульного листа (л. 1b), как и во всей рукописи, текст обрамлен в рамку красного цвета. По обеим сторонам листа в оградке нарисованы две ступы. Между ними находится семь строк текста. Первая, четвертая и последняя строки написаны красной тушью.

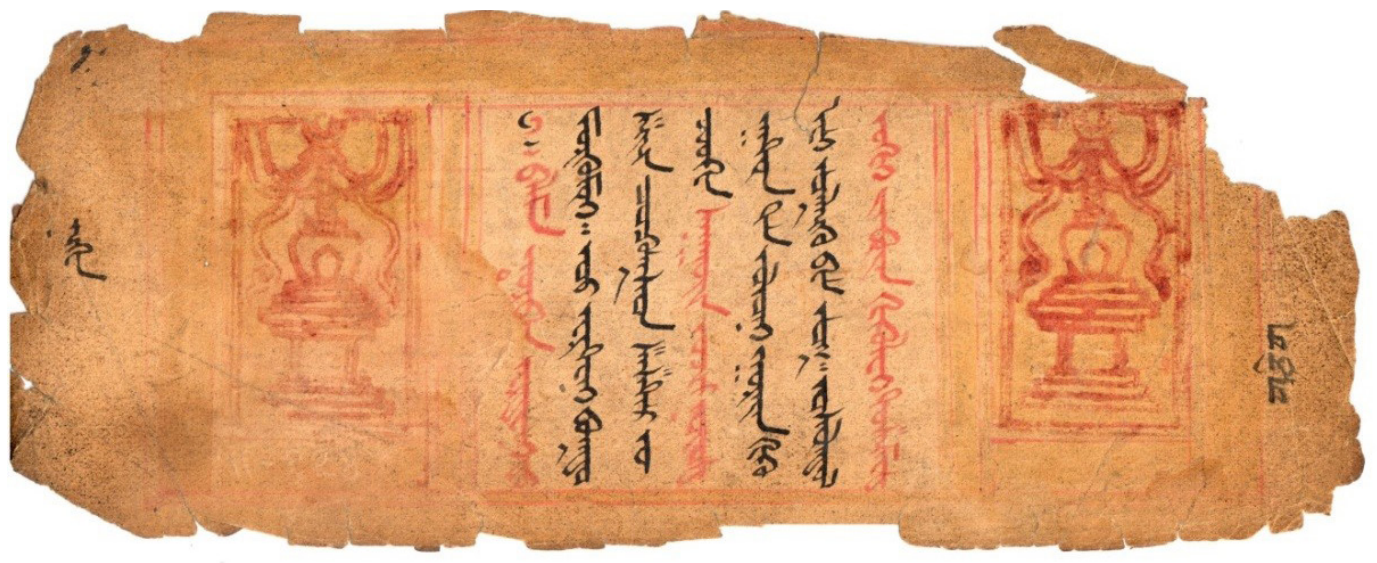

Фото 2. Лист 1b. рукописи «Оуоuni tülkü̈̈r kemēkü sudūr orošiboi».

Photo 2. Page $1 b$ of the manuscript «Oyouni tülkü̈̈r kemēkü sudūr orošiboi».

В самом тексте рукописи красной тушью выделены слова, отражающие понятия буддизма (blama'лама', rurban erdeni - 'три драгоценности', šajin - 'религия', burxan - 'Будда', bodhi möri - 'святой путь' и др.), а также титулы (поуо̄ - 'нойны', ха̄n küтün - 'хан', tüsimēd - 'сановники') и имя Чингис-хана (Čingges boqdo). Традиционно выделение отдельных слов и строк красным цветом в рукописях имело как сугубо практическое назначение, так и эстетическое начало. Определенные по счету строки, выделенные красной тушью с обеих сторон листа, придавали рукописной книге визуальную притягательность и в то же время технически делили текст на три части, что способствовало удобному чтению (Бичеев, 2018: 11). В нашем случае переписчик выделяет лишь одно слово или выражение на некоторых листах.

«Ключ разума» - оригинальное сочинение старописьменной монгольской литературы жанра поучений или наставлений (сургалов), автором которого, согласно установившейся традиции приписывать сочинения выдающимся личностям, назван сам Чингис-хан (Михайлов, 1969: 69; Яхонтова, 1992: 138). Текст этого наставления был известен и ойратам, о чем свидетельствует не только рассматриваемая нами рукопись «Oyouni tülküür kemēkü sudūr orošiboi» из НM РТ, но также и тринадцать других списков этого 
сочинения на «ясном письме», хранящихся в России, Монголии и Китае (Сазыкин, 1988: № 80; Uspensky, 1999: № 936 (6); Gerelmaa, 2005: № 965-971; Тунгалаг, 2006: № 311-312, а также: Galdan: XGMO: 0221¹).

В одних рукописях текст поучения назван сутрой «Oуoun tülküür kemēkü touǰiyin sudūr orošibo» (Сазыкин, 1988: № 80), в других - шастрой «Oуuиni tülkü̈̈r neretü šasdar oršiba» (Gerelmaa, 2005: № 966). В названии третьей части рукописей указано, что это наставления Чингис-хана «Činggis boqdoyin oyun tülkö̈̈r orošiboi», «Xutuqtu Činggis boqdoyin nomloqson oyuuni tülköür nertü sudur orošiboi» (Gerelmaa, 2005: № 968, 971).

Вопрос о том, действительно ли эти наставления принадлежат основателю монгольского государства или это лишь дань традиции приписывать сочинения выдающимся личностям для придания им большей авторитетности, - остается открытым. Во всяком случае, в самом тексте наставлений обнаруживаются строфы, которые свидетельствуют о том, что косвенно они имеют отношение к некоторым сюжетам «Сокровенного сказания монголов». К примеру, строфа № 30.

\begin{tabular}{|l|l|l|}
\hline \multirow{3}{*}{$(30)$} & $\begin{array}{l}\text { önir kümün eb ügei bolxulā } \\
\text { önčin kümüni eleq bolxu: [6a] } \\
\text { olon kümün eyē ügei bolxulā } \\
\text { orcoq kümüni iděši bolxu: }\end{array}$ & $\begin{array}{l}\text { Большая семья, в которой нет согласия, } \\
\text { Станет посмешищем для сироты [6а]. } \\
\text { Если среди многих людей нет согласия, } \\
\text { [Они] станут добычей одного человека. }\end{array}$ \\
\hline
\end{tabular}

Содержание этого наставления не совсем понятно, если не знать истории об одном из предков золотого рода Чингис-хана - Бодончаре-мунхаге, сюжет о котором есть в тексте «Сокровенного сказания монголов» (Козин, 1941: § 23-39).

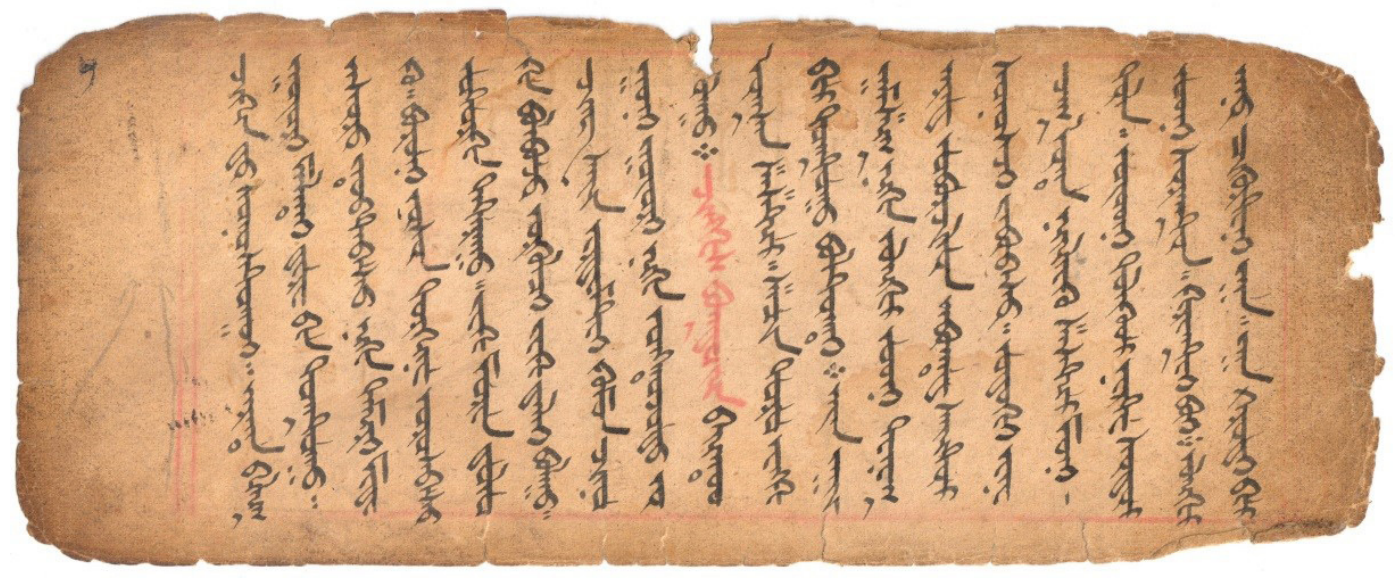

Фото 3. Лист 11b. рукописи «Оуоипi tülkü̈̈r kemēkü sudūr orošiboi». Photo 3. Page 11 b the manuscript «Oyouni tülküür kemēkü sudūr orošiboi».

В тувинском списке рукописи встречается термин «уeke durā barīd», который близок универсальному понятию «люди длинной воли». И, наконец, не совсем понятна строфа № 75 , которая некогда представляла собой связный сюжет о некоем человеке, прославившемся своим скверным характером. По всей видимости, с ходом времени, предание потеряло свою первоначальную целостность, а в тексте сохранились лишь наставления о порочащих человека поступках.

Монгольский текст «Ключ разума» и ойратский перевод этого сборника поучений частично или полностью публиковался не один раз (Попов, 1836: 1-17; Позднеев, 1900: 1-3; Damdinsürüng, 1959: 51-60; Бадмин, 1991: 64-75). Перевод текста на русский язык был осуществлен И. А. Подгорбунским (Подгорбунский, 1901). На русский и английский языки Н. С. Яхонтовой (Яхонтова, 2001: 38-53; Yakhontova, 2000: 69-137).

${ }^{1}$ Каталог ойратских рукописей Кабинета по сбору, хранению и каталогизации письменных памятников национальных меньшинств СУАР КНР для служебного пользования. Копия каталога хранится в личном архиве Б. А. Бичеева. 
Структурно содержание сочинения одни исследователи делят на три части (Damdinsürüng, 1959: 58-59; Бадмин, 1991: 64-65), другие - на две части (Яхонтова 2001: 138). В первой части, по общему мнению, содержатся поучения самого Чингис-хана с более поздними вставками буддийского характера. Во второй части поучений, которая является поздним добавлением к самостоятельно существовавшей ранней первой части, по мнению академика Ц. Дамдинсурэна, ощущается влияние «Субхашиты», в третьей же части присутствует прямое обращение к некоторым нравоучительным сюжетам известного в буддийском мире сочинения Нагарджуны «Капля, питающая людей» (Damdinsürüng, 1959: 59-60). Другие исследователи вторую и третью части рассматривают как одну вторую часть (Яхонтова, 1992: 139).

В рассматриваемом нами тувинском списке сохранилась лишь первая часть произведения, которая завершается пожеланием того, что «шастра, утвержденная Богдо Чингис-ханом будет способствовать благополучному существования государства» (Čingges boqdoyin bayizuuluqsan šaštir: saǰin törō engke-bēr toqtoxu boltuyai). Два листа с меньшей по объему второй частью сочинения, в которой помимо наставлений содержится восхваление Будды и его учения, а также пожелание тем, кто будет следовать ее предписаниям, утеряны.

Сравнительный текстологический анализ грамматических и лексических расхождений одного ойратского и девяти монгольских текстов этого сочинения, хранящихся в коллекции Института восточных рукописей РАН, был проделан Н. С. Яхонтовой. В частности, она отмечает, что «в большей или меньшей степени ойратская рукопись отличается как от всех монгольских, так и от текста, изданного Ц. Дамдинсурэном, хотя и стоит несколько ближе к последнему» (Яхонтова, 2001: 142).

Общеизвестно, что идентичных рукописей не существует. Каждая из них, в силу как объективных, так субъективных причин, в той или иной степени отличается от другой даже в пределах одного и того же сочинения, обладая какими-то своими особенностями. По этому поводу Г. И. Рамстедт с досадой отмечал, что монгольский переписчик «часто пишет одно слово верно, а десять ошибочно» (Рамстедт, 1908: 1-2). Не составляют исключения и тексты на «ясном письме», в которых расхождения в написании одного и того же слова встречаются повсеместно (Бичеев, 2019). В основном это было вызвано уровнем грамотности и диалектальной принадлежностью переписчиков, а также вследствие влияния разговорной речи. Б. Я. Владимирцов писал, что язык «ясного письма», созданного Зая-пандитой до известной степени это «монгольский литературный письменный язык, но представленный в том виде, в каком его произно-сят, т. е. читают на одном из ойратских наречий. Поэтому с одной стороны слова в языке этом являются в формах, очень близких живых, устным ойратским, а различные грамматические формы, с другой стороны, появляются в архаическом виде, конечно, не всегда, но достаточно часто» (Владимирцов, 1932: 13-14).

Несмотря на то, что исследуемая ойратская рукопись из фондов Национального музея им. АлданМаадыр Республики Тыва написана аккуратным каллиграфическим почерком, в ней обнаруживается немалое количество ошибок и неточностей. В качестве примера, приведем лишь некоторые из них. Во-первых, необходимо отметить непоследовательное написание слов с фонетической точки зрения. Это касается, в первую очередь, гласных непервых слогов: ardtu вместо aradtu - 'народу', albtu вместо albatu - 'подданные'. Разнобой в написании кратких гласных в непервых слогах слова во многом объясняется артикулярной и акустической неопределенностью (Бембеев, 2014: 207).

Отдельно следует выделить проблему с использованием знака долготы «удан», которая во многих ойратских текстах проставляется с нарушениями существующих норм. Складывается ощущение, что переписчики не придавали особого значения тому в каком месте ставить диакритический знак.Спорадически знак долготы встречается в словах, где его не должно быть: ünе̄n-yēr вместо общепринятого ӥnеn$y e \bar{r}$ ' - 'по правде', yekedkeyē - yekedkeye - 'увеличивай' и др. А в тех словах, где он необходим, переписчик его не прописывает. Причем в одних и тех же словах в тексте рукописи встречается как правильный вариант, так и ошибочный.

В тексте также выявляются случаи, когда излишняя долгота ставится путем удвоения гласной 'u', например, как в слове yabuubāsu, вместо yabubāsu - 'если уйдешь'. Н. С. Яхонтова считает, что это ничто иное как ошибки переписчиков, которые ставили эти знаки «после того, как слово или даже строка закончена» (Яхонтова, 2001: 39). Что касается долгих гласных «и» и «ӥ», то в тексте встречаются обоюдные сочетания букв, как ои / ии тои - 'плохой', uurlā - 'сердись', так ӧ̈̈ / ӥӥ - köböӥn - 'сын, ребенок', ӥсӥ̈̈kеп - 'небольшой’.

В сравнении со списком Н. С. Яхонтовой имеются некоторые лексические особенности. Так, в исследуемом тексте лексема bayiqulji - 'создать', соответствует barildoulji - ‘построить, сделать' рукописи 
Н. С. Яхонтовой (2001); поијі - 'скрывать' соответствует idxaǰ - ‘препятствовать', oudamхоlo - 'очень далекий’ соответствует иuј̈im sulu - 'отдаленный, далекий’, mürgüтüi - 'молюсь’ соответствует itegeтӥі - ‘верую’ и т. д.

Таким образом, представленный ойратский текст ориентирован на классический ойратский язык с элементами старописьменно-монгольского языка. Некоторые фонетические особенности указывают на то, что в тексте присутствует влияние разговорной речи, но эти элементы незначительны.

\section{Транслитерация и русский перевод}

\begin{tabular}{|c|c|c|c|}
\hline $\begin{array}{c}\text { № } \\
\text { строфы }\end{array}$ & Транслитерация ойратского текста ${ }^{1}$ & $\begin{array}{c}N^{\circ} \\
\text { cmpoфbl }^{2}\end{array}$ & Русский переводз \\
\hline (1) & $\begin{array}{l}\text { [la] Oyouni tülküür kemēkü sudur } \\
\text { orošiboi:: }\end{array}$ & (1) & [la] Сутра под названием «Ключ разума» \\
\hline (2) & [1b] Blama ұurban erdeni-dü mürgümüi: & (2) & $\begin{array}{l}\text { [1b] Преклоняюсь [перед] Ламой- } \\
\text { [наставником] и Тремя драгоценностями }{ }^{4} !\end{array}$ \\
\hline (3) & 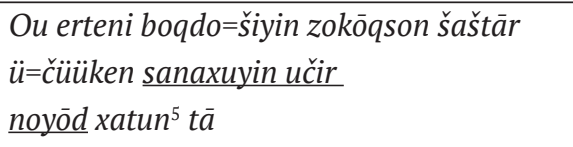 & (3) & $\begin{array}{l}\text { В далеком прошлом Августейшим, созданную } \\
\text { шастру вкратце напомню. } \\
\text { Нойоны }^{6} \text { и княгини, }\end{array}$ \\
\hline (4) & $\begin{array}{l}\text { oloni xuraya gekü=lēi öqligü-bēn öq: } \\
\text { osuldul ügei yabuya gekülei tüsimēe [2a] } \\
\text { yēn örögü: } \\
\text { arui kücü-yēn yekedkeyē gekülei ceriq-yēn } \\
\text { asurā: } \\
\text { oudam xolo jirrayā gekülei nere / bēn kicē: }\end{array}$ & (4) & $\begin{array}{l}\text { Если [хочешь] объединить многих, будь } \\
\text { щедрым. } \\
\text { Если [не хочешь] допускать оплошностей, } \\
\text { почитай чиновников. } \\
\text { Если [хочешь] увеличить свою мощь, радей о } \\
\text { войске. } \\
\text { Если [хочешь] править долго и счастливо, } \\
\text { заботься о своем имени. }\end{array}$ \\
\hline (5) & $\begin{array}{l}\text { ödör yabuqsan yabudal-yēn söni šöüqtün: } \\
\text { ičüüri gemtü yabudali nouji orki: }\end{array}$ & (5) & $\begin{array}{l}\text { Дневные деяния - обдумывай перед сном. } \\
\text { Постыдные проступки и деяния утаивай. }\end{array}$ \\
\hline (6) & $\begin{array}{l}\text { oloni dotoro üge / bēn bekilēe: } \\
\text { raqcär souxoui-du sedkil / yen šinjülē: }\end{array}$ & (6) & $\begin{array}{l}\text { Среди людей следи за своими словами, } \\
\text { Наедине - обдумывай свои мысли. }\end{array}$ \\
\hline (7) & 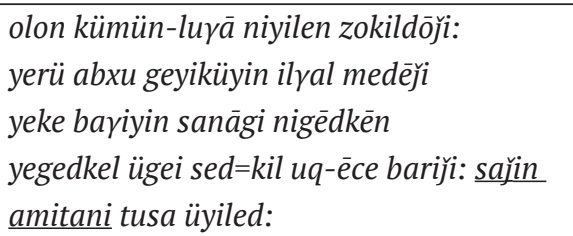 & $\begin{array}{l}\text { (7) } \\
(8)\end{array}$ & $\begin{array}{l}\text { Имея хорошие отношения со многими, } \\
\text { Знай, что принимать, а что отвергать. } \\
\text { Соедини помыслы старших и младших, } \\
\text { Возьми за основу непреходящие истины, } \\
\text { действуй на благо веры и людей. }\end{array}$ \\
\hline
\end{tabular}

${ }^{1}$ В транслитерации текста использованы следующие условные знаки: знак равенства = ставится в месте переноса части слова на другую строку в рукописи; круглые скобки ( ) заключают в себе межстрочные вставки в тексте рукописи; квадратные скобки [ ] заключают в себе восстановленную букву или слово; знак равенства в скобках [=] указывает на правильное написание слова. Знак «/» показывает перенос служебной морфемы, имеющей в тексте как слитное, так и раздельное написание. Слова, написанные красной тушью, выделены подчеркиванием. В транслитерации текста также использованы пунктационные знаки: двойное двоеточие - в конце названия произведения и строф: двоеточие - в конце строки.

${ }^{2}$ Номера поучений соответствуют нумерации в транслитерации Н. С. Яхонтовой (Яхонтова, 2001: 41-49).

${ }^{3}$ В тексте перевода в квадратные скобки заключены слова, дополняющие перевод, но отсутствующие в тексте рукописи.

${ }^{4}$ Три драгоценности - Будда, Учение и Община.

${ }^{5}$ В других списках «noyon ха̄d ta» (Вы, нойоны и ханы).

${ }^{6}$ Нойон - князь, представитель правящего рода. 


\begin{tabular}{|c|c|c|c|}
\hline (8) & 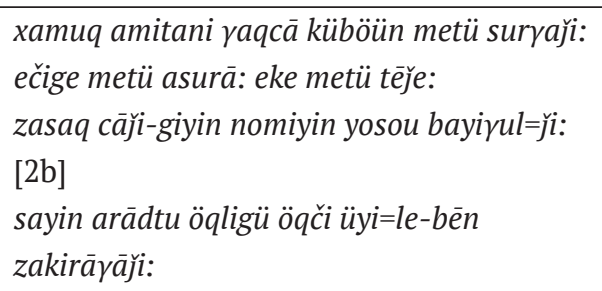 & (9) & $\begin{array}{l}\text { Подданных воспитывай как единственного } \\
\text { сына, } \\
\text { Содержи как отец, заботься как мать. } \\
\text { Руководствуйся светскими законами и } \\
\text { [законами] Дхармы1․ [2b] } \\
\text { Достойных подданных поощряй и поручай им } \\
\text { свои дела. }\end{array}$ \\
\hline (9) & 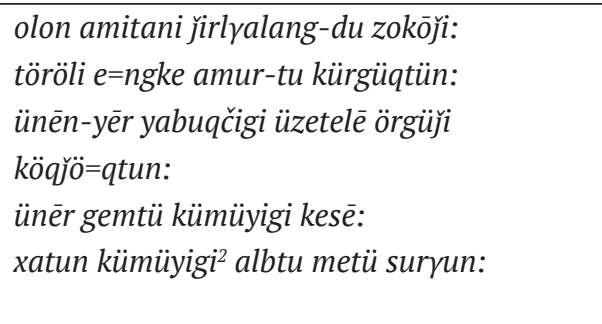 & (11) & $\begin{array}{l}\text { Подданных приведи к благоденствию, } \\
\text { Государство приведи к миру и благу. } \\
\text { Того, кто истинно правдив воочию возвышай } \\
\text { и пощряй, } \\
\text { Человека, действительно виновного, } \\
\text { наказывай. } \\
\text { Княгиню [и сына] наставляй наравне с } \\
\text { подданными. }\end{array}$ \\
\hline (10) & $\begin{array}{l}\text { kedüi kedün jüliyin kerēgi: } \\
\text { nigen ödöriyin kereq metü bodōji: } \\
\text { törö=yin bangbayi-gi dayisuni bangbayidu } \\
\text { adali bolyōji: }\end{array}$ & (12) & $\begin{array}{l}\text { Дела будущих лет обдумывай, } \\
\text { как и насущные дела одного дня. } \\
\text { Оборону государства приведи соответственно } \\
\text { мощи неприятеля. }\end{array}$ \\
\hline (11) & $\begin{array}{l}\text { beyeyin amur ülü xarā: } \\
\text { busudiyin üyile-ëce [ülü] uyidun yabuubāsu } \\
\text { dēdüs yekešiyin yabudal oyiro gēkü: }\end{array}$ & (13) & $\begin{array}{l}\text { Не радей о собственном благополучии, } \\
\text { Не тяготись деяний [на благо] других, } \\
\text { Скажут, [что твои деяния] подобны деяниям } \\
\text { великих предков. }\end{array}$ \\
\hline (12) & 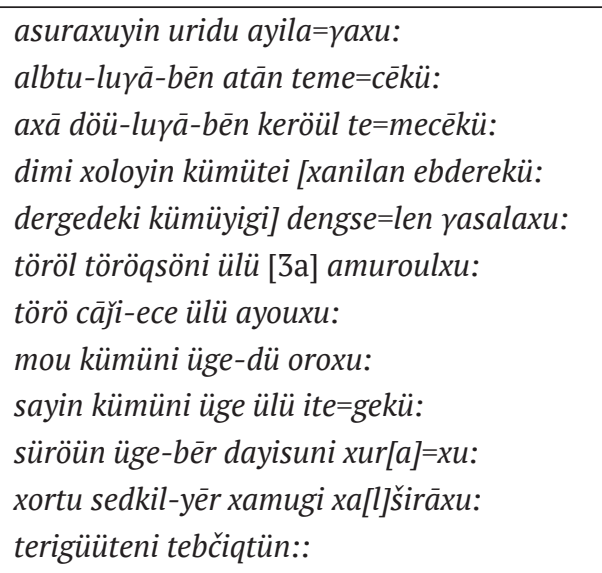 & (14) & $\begin{array}{l}\text { Сначала запугать, а затем поучать, } \\
\text { Быть с подданными в раздоре, } \\
\text { Ссориться с родными братьями, } \\
\text { По пустякам разрушать дружбу с дальними } \\
\text { [знакомыми], } \\
\text { Причинять страдания, беспокоя тех, кто } \\
\text { рядом, } \\
\text { Не давать покоя [За] своим родным, } \\
\text { Не бояться законов государства, } \\
\text { Доверять словам скверного человека, } \\
\text { Не верить словам достойного человека, } \\
\text { Грубыми словами наживать врагов, } \\
\text { Злобными намерениями отпугивать других - } \\
\text { от всего этого отрекись. }\end{array}$ \\
\hline (13) & 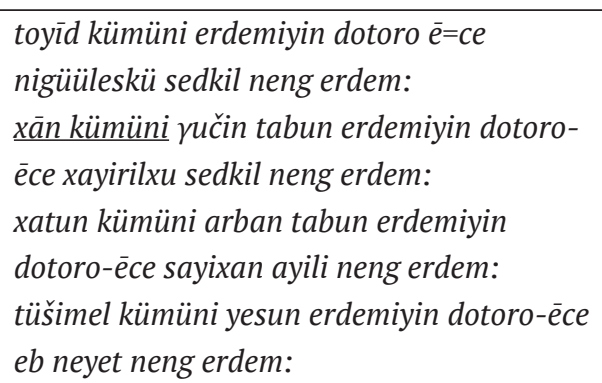 & $\begin{array}{l}(15) \\
(16) \\
(17) \\
(18)\end{array}$ & $\begin{array}{l}\text { Среди [неисчислимых] достоинств тойна } \\
\text { наивысшая добродетель - сострадание. } \\
\text { Среди тридцати пяти достоинств хана } \\
\text { наивысшая добродетель - милосердие. } \\
\text { Среди пятнадцати достоинств ханши } \\
\text { наивысшая добродетель - добрый нрав. } \\
\text { Среди девяти достоинств чиновника } \\
\text { наивысшее - стремление к согласию. }\end{array}$ \\
\hline
\end{tabular}

${ }^{1}$ Дхарма - многозначный термин, имеющий более десяти значений. В данном случае - Учение Будды.

${ }^{2}$ В других списках «köböün» (сын).

${ }^{3}$ Тойн - монах высокого происхождения. 


\begin{tabular}{|c|c|c|c|}
\hline (14) & $\begin{array}{l}\text { toyīd xamuq erdem surabāču nigüüleskü sedkil } \\
\text { ügei bol=bosu tološi ügei erdemtei bolbāču } \\
\text { tung tusa ügei: } \\
\text { xān kümün xamuq [3b] erkēgi tögüskübečü } \\
\text { xayirlaxui sed=kil ügei bögüsü xamuqtu } \\
\text { künggün bo=lumui: } \\
\text { xatun kümün xamuq sayixāni tögüskübēčü } \\
\text { ayili moutai bögüsü: xarin irēji töröküdeyin } \\
\text { buq bolumui: } \\
\text { tüsimel kümün xamuq erdem surabāču } \\
\text { tübšin sayin sedkil ügei bögüsü: xōrotu čino } \\
\text { metü ǰiqšiqdemüi: } \\
\text { teyimi tula töb eyei-bēn kicē: }\end{array}$ & $\begin{array}{l}\text { (20) } \\
(21) \\
\text { (22) }\end{array}$ & $\begin{array}{l}\text { Все неисчислимые достоинства тойна, } \\
\text { постигшего все существующие добродетели, } \\
\text { но не возродившего в себе сострадания, } \\
\text { совершенно бесполезны. } \\
\text { Хана, обретшего всю [3b] полноту власти, но не } \\
\text { знающего милосердия, народ не почитает. } \\
\text { Княжна, прекрасная собой, но со скверным } \\
\text { характером, станет обузой для родных, когда ее } \\
\text { отправят назад. } \\
\text { Не доброжелательного чиновника, даже } \\
\text { обучившегося всем достоинствам, будут } \\
\text { чураться как злобного волка. } \\
\text { Поэтому стремись к согласию [со всеми]. }\end{array}$ \\
\hline (15) & 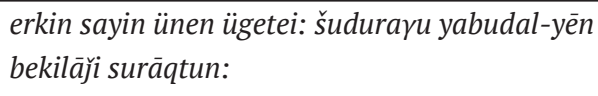 & (24) & $\begin{array}{l}\text { Твердо придерживайся правильной, правдивой } \\
\text { речи и честного поведения. }\end{array}$ \\
\hline (16) & 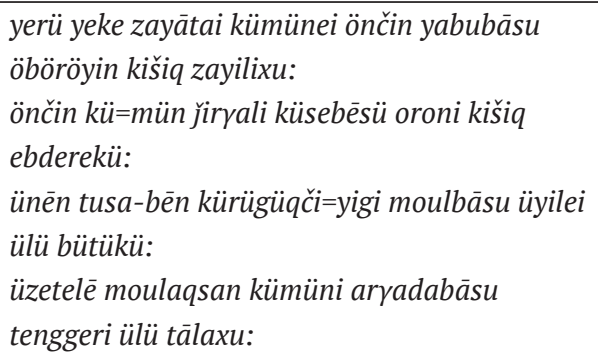 & (25) & $\begin{array}{l}\text { Если человек великого предназначения будет } \\
\text { одинок, лишиться своей судьбы. } \\
\text { Если одинокий человек возжелает счастья для } \\
\text { себя, то разрушит счастье страны. } \\
\text { Оклеветав достойного человека, не добьешься } \\
\text { нужного результата. } \\
\text { Перехитрив пусть и плохого человека, не } \\
\text { обретешь благосклонности тэнгриевㄹ. }\end{array}$ \\
\hline (17) & 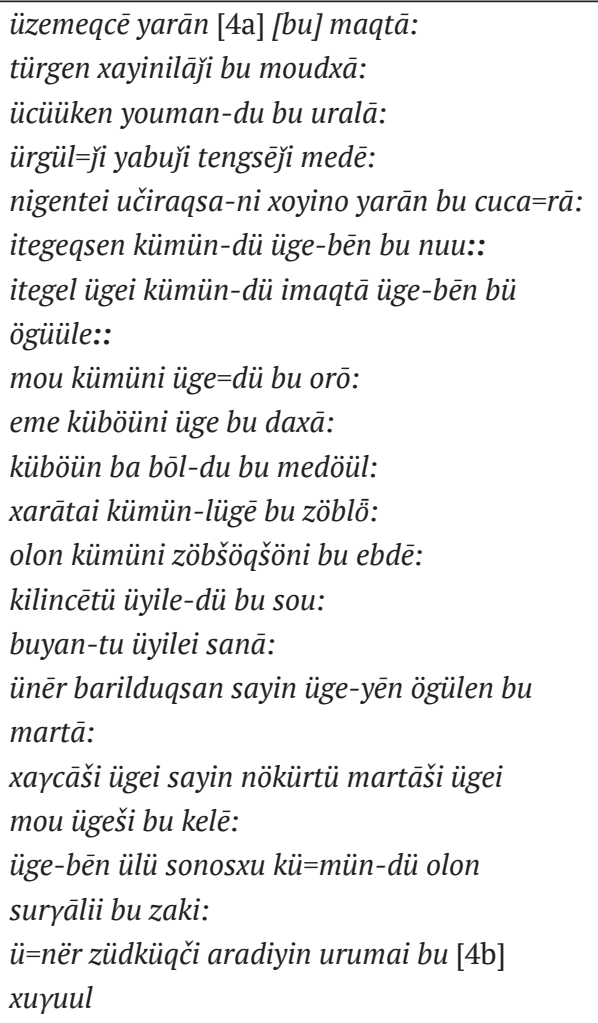 & (26) & $\begin{array}{l}\text { Не торопись восхвалять того, [4а] кого видишь } \\
\text { впервые. } \\
\text { Не оговаривай того, с кем только подружился. } \\
\text { Не проявляй характера по мелочам. } \\
\text { Долгим знакомством, узнавай [человека]. } \\
\text { С одной встречи, не спеши выказывать своего } \\
\text { отягощения знакомством. } \\
\text { Не таи слова от того, кому доверяешь, } \\
\text { Никогда не делись сокровенным с тем, кому не } \\
\text { доверяешь. } \\
\text { Не внимай слова плохого человека. } \\
\text { Не следуй словам женщины и сына. } \\
\text { Не говори о сокровенном с сыном и рабом. } \\
\text { Не доверяй коварному человеку. } \\
\text { Не нарушай одобренного всеми людьми. } \\
\text { Не находись в греховных деяниях. } \\
\text { Помни о праведных деяниях. } \\
\text { Не забывай говорить слова, которым ты } \\
\text { действительно придерживаешься. } \\
\text { Не говори плохих слов, которые не забываются, } \\
\text { лучшему другу. } \\
\text { Не поучай тех, кто не внемлет твоим словам. } \\
\text { Не охлаждай сердца преданного тебе [4b] народа. }\end{array}$ \\
\hline
\end{tabular}

${ }^{1}$ Тэнгрии - боги-небожители. 


\begin{tabular}{|c|c|c|c|}
\hline (18) & $\begin{array}{l}\text { üzemeqcē yarān maqtād: } \\
\text { učiruldun xayinilāji rayixaqdād } \\
\text { u=dul ügei keröldün urbāǰi } \\
\text { irēd:inēji yabuqči üzetelēe } \\
\text { mou arād müni tula ötör zayilā: }\end{array}$ & (27) & $\begin{array}{l}\text { [Кто] впервые увидев, хвалит, } \\
\text { При первой же встрече восхищается, } \\
\text { Потом разругавшись, уходит, Вернувшись, } \\
\text { улыбается - плохой человек. Сторонись } \\
\text { такого знакомства. }\end{array}$ \\
\hline (19) & $\begin{array}{l}\text { dēre yeke omoq sedkil barīd: } \\
\text { dimi mou beye / bēn rayixuulād } \\
\text { dēdüšiyin yosōr yabuq=či teneq } \\
\text { arādi ičüüri metü: } \\
\text { töün / ēce ötörkēn zayilā: }\end{array}$ & (28) & $\begin{array}{l}\text { [Человек], неимоверного высокомерия, } \\
\text { Выставляющий напоказ пустого себя, } \\
\text { Глупец, следующий по пути высших, - } \\
\text { Постыдный [представитель народа], } \\
\text { Сторонись такого человека. }\end{array}$ \\
\hline (20) & $\begin{array}{l}\text { kiling yeketü=yigi aryā-bēr: } \\
\text { kilincē yeketüyigi nom / yēr tedkü: }\end{array}$ & (29) & $\begin{array}{l}\text { Гневного - убеждай терпением, } \\
\text { Грешного - убеждай Учением. }\end{array}$ \\
\hline (21) & 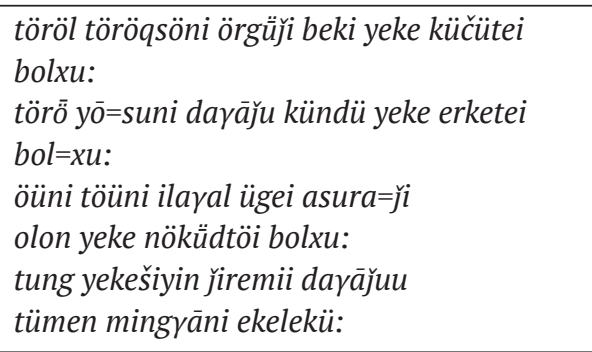 & (30) & $\begin{array}{l}\text { Способствуя благополучию рода, обретаешь } \\
\text { большую мощь. } \\
\text { Умело управляя государством, обретаешь } \\
\text { почитание и огромную власть. } \\
\text { Опекая всех и не делая различия, } \\
\text { Обретешь много преданных друзей. } \\
\text { Следуя традициям великих предков, } \\
\text { Положишь начало тумэнам루 и тысячам. }\end{array}$ \\
\hline (22) & $\begin{array}{l}\text { xoloyin kümün-dü tusa kürügü=bēsü } \\
\text { nerēn-inu dourisxu: } \\
\text { oyiriyin [5a] kümündü öqligü öqbōsü } \\
\text { eb eyetei bolōd küčün nemekü: }\end{array}$ & (31) & $\begin{array}{l}\text { Оказывая помощь дальним имя свое } \\
\text { прославишь. } \\
\text { Одаривая близких людей, установишь мир и } \\
\text { увеличишь [свою] мощь. }\end{array}$ \\
\hline (23) & 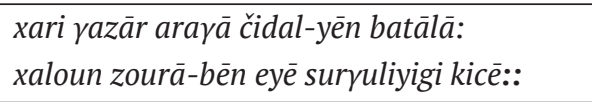 & (32) & $\begin{array}{l}\text { В чужих краях крепи мощь и умение, } \\
\text { Среди близких стремись к согласию. }\end{array}$ \\
\hline (24) & 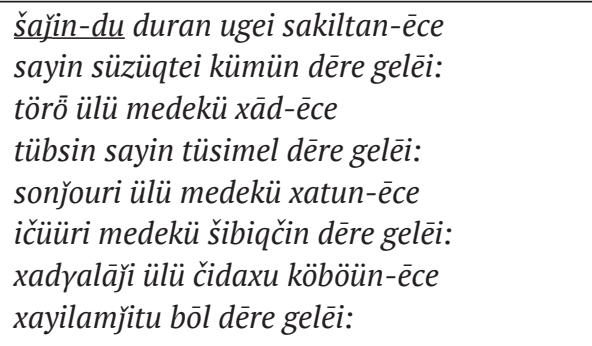 & $\begin{array}{l}(33) \\
(34) \\
(34 \mathrm{a}) \\
(35)\end{array}$ & $\begin{array}{l}\text { Благочестивый мирянин лучше давшего обет, } \\
\text { но не любящего веру [монаха]. } \\
\text { Честный, рассудительный чиновник, } \\
\text { Лучше не знающего правления хана. } \\
\text { Приличная служанка лучше, } \\
\text { Не знающей стыда госпожи. } \\
\text { Заботливый раб лучше сына, не умеющего } \\
\text { сохранить [наследство]. }\end{array}$ \\
\hline (25) & $\begin{array}{l}\text { xaram sedkil tušā: } \\
\text { xatou sedkil ǰidā: } \\
\text { xarā sanān xōron: }\end{array}$ & (36) & $\begin{array}{l}\text { Жадность - путы, } \\
\text { Жестокость - копье, } \\
\text { Зависть - яд. }\end{array}$ \\
\hline (26) & $\begin{array}{l}\text { xayinilaqsan nökür-yën xōro=bāsu } \\
\text { xayirā beye-bēn xorōqsan metü boluyu: }\end{array}$ & (37) & $\begin{array}{l}\text { Лишить жизни друга, } \\
\text { Все равно, что лишить жизни себя. }\end{array}$ \\
\hline (27) & $\begin{array}{l}\text { mou arādtu ülemj̈i yeke üge bu kelē: } \\
\text { öšiül bolxu: } \\
\text { mungxaq kümün / luүā üge bu temcēe } \\
\text { xoyino xarin ičüü(ri) [5b] bolxu: }\end{array}$ & $\begin{array}{l}(38) \\
(39) \\
\end{array}$ & $\begin{array}{l}\text { Не говори важных слов простым людям, } \\
\text { станешь посмешищем. } \\
\text { Не спорь с глупцом, } \\
\text { Иначе стыда [5b] не оберешься. }\end{array}$ \\
\hline (28) & $\begin{array}{l}\text { omoqtoi ücü̈̈ken kümün } \\
\text { ür=gülǰi yeke mergēdtü xaldabāsu } \\
\text { ötör=kēn šintārxuyin temdeq: } \\
\text { genetē sayiraq=san arād ketürkei } \\
\text { yekestü xaldabasu: gemsīji ülü baraqdaxu: }\end{array}$ & $(41)$ & $\begin{array}{l}\text { Если высокомерный и малознающий человек, } \\
\text { будет постоянно привязываться к мудрецам, } \\
\text { очень скоро окажется униженным. } \\
\text { Если внезапно обогатившийся простолюдин, } \\
\text { будет привязываться к великим [людям],-- } \\
\text { раскаянию его не будет конца. }\end{array}$ \\
\hline
\end{tabular}

${ }^{1}$ Тумэн - десять тысяч. Традиционное для монголов деление народа и войска на сотни, тысячи и тумэны. 


\begin{tabular}{|c|c|c|c|}
\hline (29) & 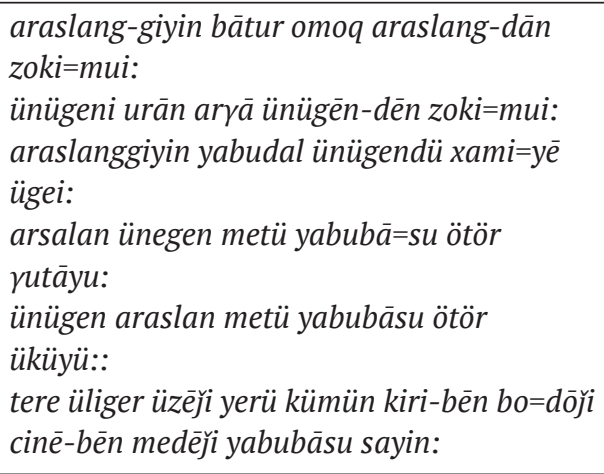 & $(42)$ & $\begin{array}{l}\text { Львиная храбрость соответствует только льву, } \\
\text { Лисья хитрость соответствует только лисе. } \\
\text { Львиные повадки лисе ни к чему. } \\
\text { Лев, уподобившийся лисе, очень скоро станет } \\
\text { посмешищем. } \\
\text { Лиса, уподобившаяся льву, очень скоро } \\
\text { погибнет. } \\
\text { Будет хорошо если согласно этой притче } \\
\text { человек, осознав свой статус и возможности, } \\
\text { станет поступать соответствующим образом. }\end{array}$ \\
\hline (30) & $\begin{array}{l}\text { yerü xoyor kümün ebtei bolxulā: } \\
\text { tömör kürē metü beki: } \\
\text { xorin kümün eb ügei bolxulā: } \\
\text { ebderēkü kürē metü kilbār: } \\
\text { önir kümün eb ügei bolxulā } \\
\text { önčin kümüni eleq bolxu: [6a] } \\
\text { olon kümün eyē ügei bolxulā } \\
\text { orcoq kümüni idēši bolxu: } \\
\text { cubu=ǰi yabuqsan bars-ēce } \\
\text { cuqlāji bayi=qsan šāzarai dēre gelēi: } \\
\text { teyimi(yin) tula eb eyē-yēn beki boluyu: }\end{array}$ & $\begin{array}{l}(45) \\
(46)\end{array}$ & $\begin{array}{l}\text { Два человека, живущих в согласии, подобны } \\
\text { железной крепости. } \\
\text { Двадцать человек, не имеющих согласия, } \\
\text { подобны не укрепленной крепости, легкой } \\
\text { [для завоевания]. } \\
\text { Большая семья, в которой нет согласия, } \\
\text { Станет посмешище для сироты [6а]. } \\
\text { Если среди многих людей нет согласия, } \\
\text { [Они] станут добычей одного человека. } \\
\text { Собравшиеся в одну стаю сороки, } \\
\text { Сильнее одиноко бредущего барса. } \\
\text { Поэтому крепите свое согласие. }\end{array}$ \\
\hline (31) & $\begin{array}{l}\text { amaraq xanilaqsan kümün-dü } \\
\text { abuyin kümüni üge / bēr bu ourlā: } \\
\text { aǰiqlaji oyōto xarin beye-bēn šö̈̈qtün: }\end{array}$ & $\begin{array}{l}(47) \\
(48)\end{array}$ & $\begin{array}{l}\text { Не сердись на давнего друга } \\
\text { Исходя из сказанного о нем другими. } \\
\text { Внимательно анализируй все сам. }\end{array}$ \\
\hline (32) & 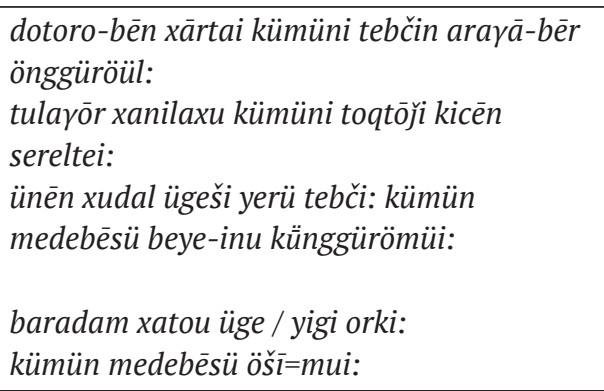 & (49) & $\begin{array}{l}\text { Уважаемого тобой человека провожай с } \\
\text { почтением, } \\
\text { Когда начинаешь дружить с человеком, } \\
\text { проявляй бдительность. } \\
\text { Воздержись от правильных и ложных слов, } \\
\text { узнав о них люди, потеряют уважение к тебе. } \\
\text { Не говори хвастливых и грубых слов, узнав о } \\
\text { них, люди затаят месть. }\end{array}$ \\
\hline (33) & $\begin{array}{l}\text { xularai xudal ene nasuni i=čüüri } \\
\text { ecüs-tü tamuyin buq:: } \\
\text { öüni ertēn-ēce tasul: }\end{array}$ & $(52)$ & $\begin{array}{l}\text { Ложь и воровство - стыд в этой жизни. } \\
\text { Потом - тяготы ада. } \\
\text { Заблаговременно отрекись от этого. }\end{array}$ \\
\hline (34) & $\begin{array}{l}\text { ariun yabudaltu blamayigi burxan metü } \\
\text { taki: asaral [6b] dēdü noyogi tenggeri metü } \\
\text { kündülē: }\end{array}$ & (53) & $\begin{array}{l}\text { Праведного ламу почитай как Будду. } \\
\text { Заботливого [6b] нойона почитай как тенгрия- } \\
\text { небожителя. }\end{array}$ \\
\hline (35) & 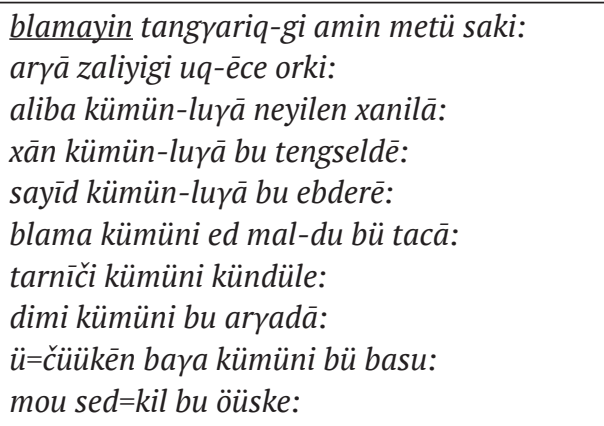 & $\begin{array}{l}(53) \\
(54)\end{array}$ & $\begin{array}{l}\text { Монашеский обет храни пуще жизни. } \\
\text { Леность пресекай в корне. } \\
\text { Старайся быть в ладу со всеми людьми. } \\
\text { С ханом не равняйся. } \\
\text { С министром не ссорься. } \\
\text { Не завидуй имуществу ламы. } \\
\text { Почитай заклинателей. } \\
\text { Пустому человеку не способствуй. } \\
\text { Человека ниже себя не унижай. } \\
\text { Не порождай не праведных воззрений. }\end{array}$ \\
\hline
\end{tabular}

${ }^{1}$ Поучения № 50 в нашей рукописи нет. 


\begin{tabular}{|c|c|c|c|}
\hline (36) & $\begin{array}{l}\text { burxan tenggeriyigi sayitur taki: } \\
\text { noyōd sayidi bu dayiri: } \\
\text { ayouxu ičüüri-gi aǰiqlaǰ medē:: }\end{array}$ & $(55)$ & $\begin{array}{l}\text { Усердно почитай Будду и тенгриев- } \\
\text { небожителей. } \\
\text { Не оскорбляй нойонов и министров. } \\
\text { Размышляй над тем, что постыдно. }\end{array}$ \\
\hline (37) & $\begin{array}{l}\text { öböröyin zang ayiliyigi ariudxān šinǰilē: } \\
\text { öširkü dayisun-du cusu / bēn bu üzüül: } \\
\text { öšötü kümün-dü mou / bēn bu üzüül: }\end{array}$ & $\begin{array}{l}\text { (56) } \\
(57)\end{array}$ & $\begin{array}{l}\text { Свой характер подвергай тщательному } \\
\text { анализу. } \\
\text { Заклятому врагу не показывай своей крови. } \\
\text { Заклятому сопернику не показывай своей } \\
\text { слабости. }\end{array}$ \\
\hline (38) & 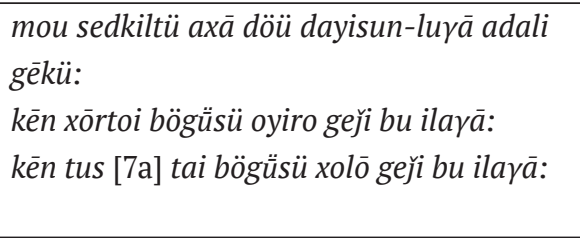 & (59) & $\begin{array}{l}\text { Говорят, что плохие братья подобны врагам. } \\
\text { Если кто опасен, не щади, считая его близким } \\
\text { [родственником]. } \\
\text { Если кто полезен, [7а] не отвергай, считая его } \\
\text { чужим [не родственником]. }\end{array}$ \\
\hline (39) & $\begin{array}{l}\text { zöbtöi yabuxu kümüni bu daru: } \\
\text { buruutei yabuxu kümüni bu asura: }\end{array}$ & $(60)$ & $\begin{array}{l}\text { Праведных не притесняй. } \\
\text { Неправедных не поддерживай. }\end{array}$ \\
\hline$(40)$ & $\begin{array}{l}\text { (mou) arādi yekede xayirilbāsu xarin beye- } \\
\text { dü xalidāxu: } \\
\text { sayin arādi mou=lbāsu xoyino öbör-yēn } \\
\text { gemsikü: } \\
\text { ünēn xudal sayin mougi ilayaǰi medekülēe } \\
\text { yeke kereqtei: }\end{array}$ & (61) & $\begin{array}{l}\text { Если слишком потворствовать плохим } \\
\text { аратам, сам уподобишься им. } \\
\text { Если обвинять верных аратов, потом будешь } \\
\text { сожалеть [об этом]. } \\
\text { Важно различать правду и ложь, } \\
\text { хорошее и плохого. }\end{array}$ \\
\hline (41) & 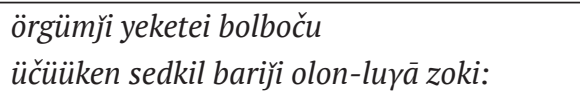 & (62) & $\begin{array}{l}\text { Будучи высоко возвышен, } \\
\text { Будь скромным и в согласии со всеми. }\end{array}$ \\
\hline (42) & $\begin{array}{l}\text { kümü=ni nüüri xaril ügei üyilen tulādu } \\
\text { kürtelē züdkēji bütēi: }\end{array}$ & (63) & $\begin{array}{l}\text { Не заглядывая в глаза другим, } \\
\text { Упорно доводи свое дело до конца. }\end{array}$ \\
\hline (43) & $\begin{array}{l}\text { xariyin üyilegi nasun-du serē: } \\
\text { xaloun zurā eb eye-bēn kicēe: }\end{array}$ & (64) & $\begin{array}{l}\text { В чужих делах всегда будь настороже, } \\
\text { Среди своих - радей о согласии. }\end{array}$ \\
\hline (44) & $\begin{array}{l}\text { dēdüs=yigi kündülē: } \\
\text { dorōdusiyigi asurā: }\end{array}$ & $(65)$ & $\begin{array}{l}\text { Высших почитай, } \\
\text { Низших опекай. }\end{array}$ \\
\hline (45) & $\begin{array}{l}\text { burxān saǰin-du ami-bēn tebči: } \\
\text { busudiyin üyile-dü beye-bēn orki:: }\end{array}$ & (66) & $\begin{array}{l}\text { Жизнь посвяти учению Будды, } \\
\text { Себя отдай на благо других. }\end{array}$ \\
\hline (46) & $\begin{array}{l}\text { bültiril ügei yabubāsu boqdošiyin [7b] } \\
\text { yabudal oyirō gēkü: }\end{array}$ & (67) & $\begin{array}{l}\text { Если не оступаться, [7b] то приблизишься к } \\
\text { деяниям высших. }\end{array}$ \\
\hline (47) & $\begin{array}{l}\text { samuun mou beye-bēn sayin-du bodun } \\
\text { sanād yeke durā barīd } \\
\text { ararā xourāǰi ide=küyigi surāju } \\
\text { dorōdu arādi darāǰi yabuqči kümüni } \\
\text { adousuni ǰergēe / dü oyirō gēkü: }\end{array}$ & (68) & $\begin{array}{l}\text { Распутник, высокого мнения о себе, } \\
\text { Возомнивший о великом, } \\
\text { Приученный к обману и взяткам, } \\
\text { Притесняющий простых людей, - Такой } \\
\text { [человек] близок к животным. }\end{array}$ \\
\hline (48) & $\begin{array}{l}\text { ili nüürtü maqtād: } \\
\text { dalda nüürtü moulā: } \\
\text { nuuǰi sur=qsani } \\
\text { inēdün nādun-yēr önggü=röülün yabuqči } \\
\text { kümüni kesebēsü: ulam xoyitudā tus bišiu: }\end{array}$ & (69) & $\begin{array}{l}\text { Если человека, который } \\
\text { Хвалит в лицо, а за спиной хулит, } \\
\text { Втайне сказанное ему } \\
\text { Обращает в смех и шутку - наказать, } \\
\text { То разве это не принесет ему пользы в } \\
\text { будущем. }\end{array}$ \\
\hline
\end{tabular}




\begin{tabular}{|c|c|c|c|}
\hline (49) & 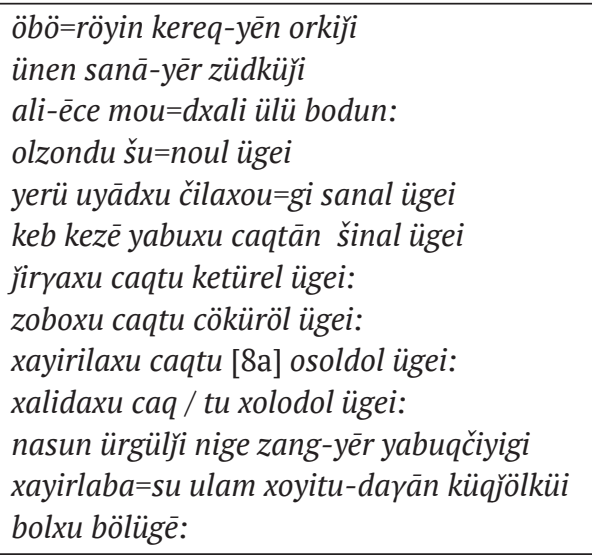 & $\begin{array}{l}(70) \\
(71)\end{array}$ & $\begin{array}{l}\text { [Таких, кто] отставив свои интересы, } \\
\text { Действует с правильным намерением, } \\
\text { Не мыслит о плохом и порочном. } \\
\text { Не стремится к корысти, } \\
\text { Не страшится печалей и бедствий, } \\
\text { Никогда не отчаивается, } \\
\text { Во время веселья не нарушает норм, } \\
\text { Во время страданий не сгибается, } \\
\text { В благое время [8а] не подводит, } \\
\text { В тяжелое время не отдаляется, } \\
\text { Всегда действует с постоянством, - } \\
\text { Поддерживать, то в будущем можно будет } \\
\text { достичь процветания. }\end{array}$ \\
\hline$(50)$ & $\begin{array}{l}\text { yerü kümüni axuyin üyiles zergeteyin tula } \\
\text { amitani sed=kil medeši ügei: } \\
\text { zalxai xourmaq aryatai olon bui: }\end{array}$ & (71) & $\begin{array}{l}\text { Поскольку деяния людей не одинаковы, } \\
\text { Понять намерения людей невозможно. } \\
\text { Коварства и лжи великое множество. }\end{array}$ \\
\hline (51) & $\begin{array}{l}\text { tustai sanayigi nasuda kicēǰ yabumui: } \\
\text { tustu sayin kümün usun metü: } \\
\text { tung mou kümün modun metü: }\end{array}$ & (72) & $\begin{array}{l}\text { Всегда усердствуй в помощи [другим]. } \\
\text { Полезный человек подобен воде, } \\
\text { Подлый человек подобен дереву. }\end{array}$ \\
\hline$(52)$ & $\begin{array}{l}\text { busudiyin izou=ri-tu gemtü yabudali nuuj̆i } \\
\text { orki: öböriyin beyei maqtāl ügei üyile-bēn } \\
\text { šinǰiqün: }\end{array}$ & (73) & $\begin{array}{l}\text { Утаивай коренные проступки других, } \\
\text { Не восхваляй себя, а размышляй над своими } \\
\text { действиями. }\end{array}$ \\
\hline (53) & $\begin{array}{l}\text { saǰin amitani tusayigi caq tutum üyiledǰi } \\
\text { yabubāsu: } \\
\text { keb kezē ükül zobolong ügei bol=xu: }\end{array}$ & (74) & $\begin{array}{l}\text { Если постоянно радеть о благе религии } \\
\text { и живых существ, то никогда не узнаешь } \\
\text { страданий после смерти. }\end{array}$ \\
\hline (54) & $\begin{array}{l}\text { nasuni šidiš ese oloqsani tula } \\
\text { möngkü busuyigi sanaxu kereqtei [8b] } \\
\text { ayoultu tamuyin xalyayigi ese xāqsani tula } \\
\text { kilincē-ēce zayilaxu kereqtei: }\end{array}$ & $(75)$ & $\begin{array}{l}\text { Поскольку волшебного [средства] для жизни } \\
\text { нет, надо помнить о невечном. [8b] } \\
\text { Поскольку врата ада не закрыты, } \\
\text { надо отречься от грехов. }\end{array}$ \\
\hline (55) & 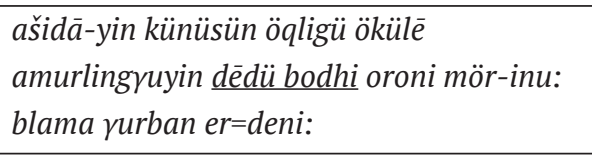 & (76) & $\begin{array}{l}\text { Подношение - накопление для будущего, } \\
\text { Путь в страну блаженства - } \\
\text { Лама-наставник и Три драгоценности. }\end{array}$ \\
\hline (56) & $\begin{array}{l}\text { mergediyin gegēni üzüül ügei nom } \\
\text { nomloqči [blama] } \\
\text { noyodiyin gegeni ü=züül ügei: törō } \\
\text { yosun xoyori keleqči ene xoyor <blama> } \\
\text { [endüürekü] kemēkü: }\end{array}$ & (77) & $\begin{array}{l}\text { [Лама], проповедующий Учение, не ссылаясь } \\
\text { на мудрецов, } \\
\text { [Нойон], рассуждающий о государстве, не } \\
\text { ссылаясь на лучших нойонов - } \\
\text { Эти двое ошибаются. }\end{array}$ \\
\hline (57) & $\begin{array}{l}\text { gem kēbēsü cāji berke: } \\
\text { kilincē kēbēsü tamu berke: }\end{array}$ & (78) & $\begin{array}{l}\text { Если совершил преступление - закон суров. } \\
\text { Если совершил грех - ад суров. }\end{array}$ \\
\hline (58) & 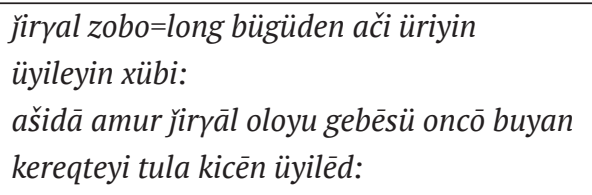 & (79) & $\begin{array}{l}\text { Все наслаждения и страдания - результат } \\
\text { кармы. } \\
\text { Хочешь обрести покой, - усердствуй в } \\
\text { накоплении благие результатов. }\end{array}$ \\
\hline (59) & 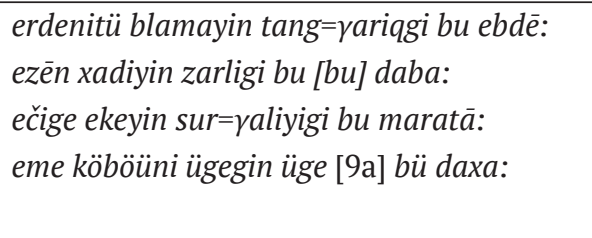 & (80) & $\begin{array}{l}\text { Не нарушай клятву, [данную] драгоценному } \\
\text { Ламе-наставнику. } \\
\text { Не преступай повелений хана. } \\
\text { Не забывай наставления родителей. } \\
\text { Не следуй словам женщины и детей. }\end{array}$ \\
\hline
\end{tabular}




\begin{tabular}{|c|c|c|c|}
\hline (60) & $\begin{array}{l}\text { öüne-ēce nomloqson-inu suduriyin dēdügi } \\
\text { sonosxuyin dēdü: }\end{array}$ & $(82)^{1}$ & $\begin{array}{l}\text { Поведанные далее наивысшие [наставления] } \\
\text { сутры - важнейшие для слушания. }\end{array}$ \\
\hline (61) & 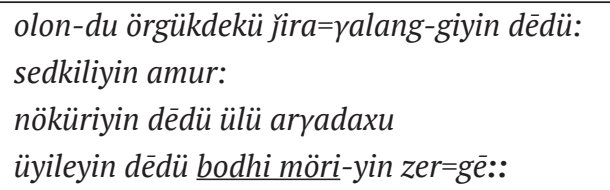 & (82) & $\begin{array}{l}\text { Высшее счастье, поднесенное для всех - } \\
\text { спокойствие ума, } \\
\text { Высший друг - тот, кто не предаст, } \\
\text { Высшее деяние - ступени святости. }\end{array}$ \\
\hline (62) & $\begin{array}{l}\text { xōrotōi bögōsü kümünì (čü) tebči: } \\
\text { tustai bögüsü dayisuni čü asu=rā: }\end{array}$ & (83) & $\begin{array}{l}\text { Опасного, пусть он и свой, изгоняй. } \\
\text { Полезного, пусть он и враг, привечай. }\end{array}$ \\
\hline (63) & $\begin{array}{l}\text { olon nidün bui bolbōču üčüüken zulayin } \\
\text { gerel söni-dü tustai kemēqčiyin üliger-inu: } \\
\text { olon kümün bui bolboču olon cuqlaqsani } \\
\text { dotoro-ēce yaqcā sayin kümün uduridun } \\
\text { kelē-kü=yinu: }\end{array}$ & (84) & $\begin{array}{l}\text { Свет маленькой лампады ночью полезен, } \\
\text { даже если много глаз. } \\
\text { Вот что говорится в притче: } \\
\text { Среди многих собравшихся беседой } \\
\text { руководит один уважаемый человек. }\end{array}$ \\
\hline (64) & 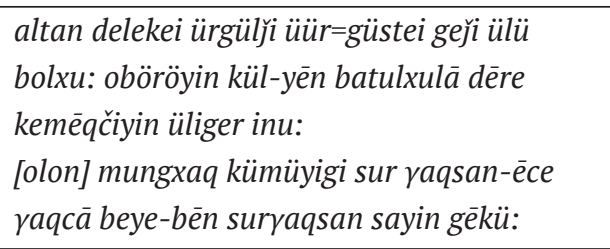 & (85) & $\begin{array}{l}\text { Нельзя сказать, что этот в этом мире везде } \\
\text { колючки, но лучше позаботиться о своих } \\
\text { ногах. Вот что говорится в притче: Вместо } \\
\text { того чтобы учить многих глупцов, [9b] лучше } \\
\text { научиться самому. }\end{array}$ \\
\hline (65) & 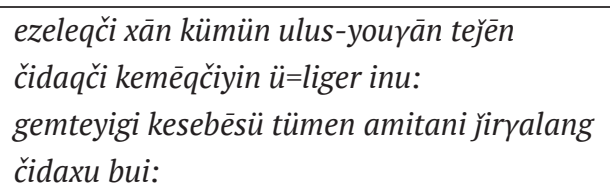 & (86) & $\begin{array}{l}\text { Властвующий хан умеет содержать свой } \\
\text { народ. Вот что говорится в притче: Умеющий } \\
\text { наказать виновного, сумеет содержать в благе } \\
\text { десятки тысяч людей. }\end{array}$ \\
\hline (66) & $\begin{array}{l}\text { ǰi=ryaxu caqtu serekü kereq: } \\
\text { zoboxu caqtu xatouǰl kereq: }\end{array}$ & (87) & $\begin{array}{l}\text { В благоденствии будь начеку. } \\
\text { В печали будь стоек. }\end{array}$ \\
\hline (67) & $\begin{array}{l}\text { dayisun ügei geǰi ìrtü meseyigi beye-ēce bu } \\
\text { xoldul: xōrotoi bögüsü kemēn nö=küri darui } \\
\text { bu sönỗ: onuǰ medeqsen kereqtei: }\end{array}$ & (88) & $\begin{array}{l}\text { Думая: «Врага [рядом] нет», - острый меч } \\
\text { далеко не откладывай. } \\
\text { Не торопись казнить друга, назвав его } \\
\text { «врагом», нужно понять причину. }\end{array}$ \\
\hline (68) & 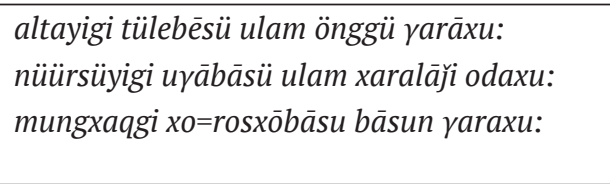 & (89) & $\begin{array}{l}\text { Если золото калить, цвет ярче станет, } \\
\text { Если мыть уголь, еще более почернеет. } \\
\text { Если задеть глупца, он станет выделять } \\
\text { нечистоты. }\end{array}$ \\
\hline (69) & 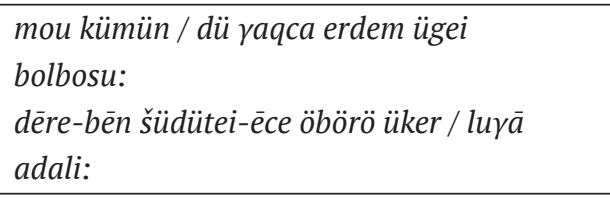 & (90) & $\begin{array}{l}\text { Пустой человек не имеющий ни одной } \\
\text { добродетели, кроме того, что имеет зубы } \\
\text { на верхней челюсти, в остальном похож на } \\
\text { корову. }\end{array}$ \\
\hline (70) & 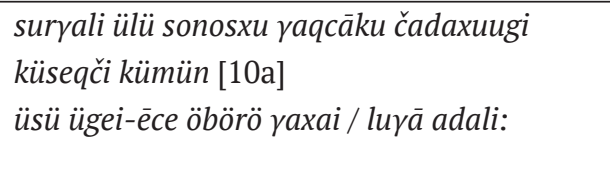 & (91) & $\begin{array}{l}\text { Человек, который не слушает поучений, } \\
\text { печется только о желудке, [10а] кроме того, } \\
\text { что у него нет щетины, в остальном похож на } \\
\text { свинью. }\end{array}$ \\
\hline (71) & 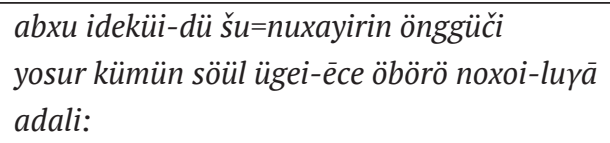 & (92) & $\begin{array}{l}\text { Человек, льстивый и жадный до взяток, } \\
\text { кроме того, что у него нет хвоста, в остальном } \\
\text { похож на собаку. }\end{array}$ \\
\hline (72) & $\begin{array}{l}\text { mou kümün-dü kürügüqsen tusa } \\
\text { xuǰirtai yazar tariqsan tarān-du adali: }\end{array}$ & (93) & $\begin{array}{l}\text { Помощь, оказанная плохому человеку, } \\
\text { Подобна семенам, брошенным на солончак. }\end{array}$ \\
\hline
\end{tabular}

${ }^{1}$ Поучения № 80-81 в нашей рукописи нет.

${ }^{2}$ В других списках «köböӥn» (сын). 


\begin{tabular}{|c|c|c|c|}
\hline (73) & $\begin{array}{l}\text { bušu youmayigi zas=ji bolumui: } \\
\text { raqcāku mou kümüyigi zaş̌i ülü bolxu: }\end{array}$ & (94) & $\begin{array}{l}\text { Все другое можно исправить, } \\
\text { Только скверного человека нельзя исправить. }\end{array}$ \\
\hline (74) & 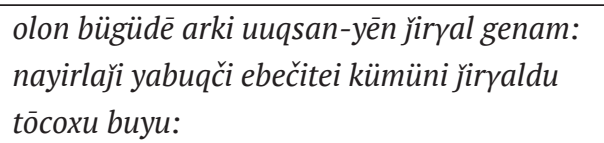 & (95) & $\begin{array}{l}\text { Многие считает питье водки счастьем, } \\
\text { Можно ли в таком случае считать счастливым } \\
\text { больного, веселящегося [на пиру]. }\end{array}$ \\
\hline$(75)$ & 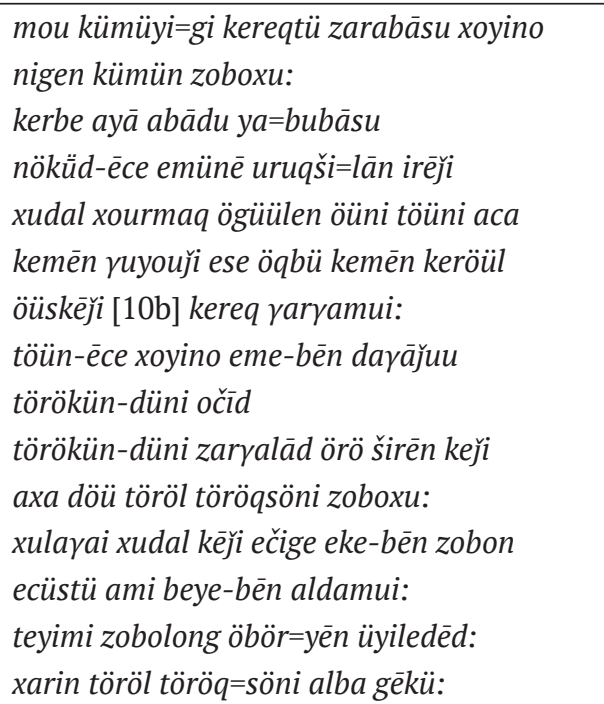 & $\begin{array}{l}\text { (96) } \\
(97)\end{array}$ & $\begin{array}{l}\text { Если поручишь дело плохому человеку, потом } \\
\text { будет страдать другой человек. } \\
\text { Если [он] возвращается с охоты раньше } \\
\text { других, говорит неправду, затем просит то } \\
\text { или другое. Утверждая, что ему ничего не } \\
\text { дали, [10b] устраивает скандалы и создает } \\
\text { проблему. } \\
\text { После этого вместе с женой едет к ее } \\
\text { родственникам, служит им. } \\
\text { Наделав больших долгов, подвергает } \\
\text { страданиям братьев и родственников. } \\
\text { Ворует, обманывает, отчего страдают } \\
\text { родители. В итоге губит свою жизнь, } \\
\text { причинив сам себе такие страдания. } \\
\text { Потом скажут, что убили родственники. }\end{array}$ \\
\hline (76) & $\begin{array}{l}\text { yerü kümüni töröl oluqsani xoyino } \\
\text { öün-ēce zayi=laxu kereqteyin tula: } \\
\text { manarār ükükü bolboču erdemi suraxu } \\
\text { kereqtei:: } \\
\text { kerbe ese surabāču xoyitu töröl / dü sayin } \\
\text { abiyās boluxuyin tula: kicēn suraqtun: }\end{array}$ & $\begin{array}{l}(99) \\
(100)\end{array}$ & $\begin{array}{l}\text { Обретя перерождение человеком, } \\
\text { От такого [поведения] надо отказаться. } \\
\text { Даже если завтра ожидает смерть, надо } \\
\text { учиться. } \\
\text { Если не учиться, то надо стараться, чтобы в } \\
\text { будущем рождении иметь хорошие условия. }\end{array}$ \\
\hline (77) & $\begin{array}{l}\text { adousun-bēr su=raxu bögütölö: } \\
\text { erdenitü kümüni tö=röl oluqsani xoyino } \\
\text { erdemi sur=xu kilbar bolumui: }\end{array}$ & $(101)$ & $\begin{array}{l}\text { Если уж обучается скотина, } \\
\text { То выучиться, обретя драгоценное рождение } \\
\text { человеком, - гораздо легче. }\end{array}$ \\
\hline (78) & $\begin{array}{l}\text { üküküyin urida amidu caqtān buyan üyilēd: } \\
\text { ötölküyin urida zalou caqtān erdem } \\
\text { suraqtun: } \\
\text { ebdēküyin urida eröül caqtan nom buyani } \\
\text { kicē: } \\
\text { ügëriküyin urida bayān caqtān ö=qligü öqči } \\
\text { sayin nere ab:: } \\
\text { büdü=küyin dörbön nökür inu }\end{array}$ & $(102)$ & $\begin{array}{l}\text { Пока смерть не настала, [11a] при жизни } \\
\text { твори благие деяния. } \\
\text { Пока старость не наступила, в молодые годы } \\
\text { учись. } \\
\text { Пока болезнь не одолела, будучи здоровым, } \\
\text { усердствуй в благодеянии. } \\
\text { Пока не обеднел, будучи в состоянии, } \\
\text { подношением заслужи хорошее имя. } \\
\text { [Это] четыре спутника успеха. }\end{array}$ \\
\hline (79) & xōsun činar oluqsan blamagi taki: & $(103)$ & $\begin{array}{l}\text { Ламу, познавшего свойство пустоты, - } \\
\text { почитай. }\end{array}$ \\
\hline$(80)$ & 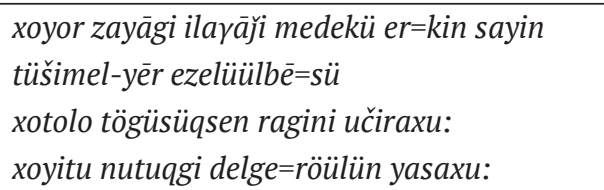 & $(104)$ & $\begin{array}{l}\text { Если согласовать с умным чиновником, } \\
\text { Умеющим различить две судьбы, } \\
\text { То обретешь совершенную рагиниㄹ, } \\
\text { Расширишь в будущем свои владения. }\end{array}$ \\
\hline
\end{tabular}

${ }^{1}$ Рагини - небесная дева. 


\begin{tabular}{|c|c|c|c|}
\hline (81) & $\begin{array}{l}\text { ükükü kümün sayin blama-ёce ауоихu: } \\
\text { ügeyirikü kümün xotōči noxoi-ēce ayouxu: } \\
\text { doroi=tuxu noyon tübšin sayin sayid / ēce } \\
\text { ayouxu: }\end{array}$ & (105) & $\begin{array}{l}\text { Человек при смерти, боится хорошего ламы. } \\
\text { Человек, теряющий свое состояние, боится } \\
\text { [лая] дворовой собаки. } \\
\text { Нойон, теряющий положение, боится умного } \\
\text { министра. }\end{array}$ \\
\hline (82) & $\begin{array}{l}\text { maši zöb yabubāsu sayin aldar nere mün: } \\
\text { ene beyeyin [11b] čikin-dü sonostoxui: } \\
\text { araүā biliq xoyori malyai dēre-bēn toqtōxu: }\end{array}$ & (106) & $\begin{array}{l}\text { Праведные деяния - это славное имя. При } \\
\text { жизни [11b] услышишь об этом. } \\
\text { Метод и мудрость подобно головному убору } \\
\text { установи над своей головой. }\end{array}$ \\
\hline (83) & $\begin{array}{l}\text { asuru rubtabāsu } \\
\text { nigen tamiri mede=kü: }\end{array}$ & (106) & $\begin{array}{l}\text { Сильное истощение [сил] } \\
\text { Познается физической нагрузкой. }\end{array}$ \\
\hline (84) & $\begin{array}{l}\text { borōni usun türgine urusbāsu ötörkēn } \\
\text { tatāraxu: } \\
\text { yeke mörēn dölö=kēn bolbōču ürgüly̌i yeke } \\
\text { dalai bolxu: }\end{array}$ & (107) & $\begin{array}{l}\text { Стремительный поток дождевой воды, столь } \\
\text { же быстро иссякает. } \\
\text { Неторопливо течение большой реки, но она } \\
\text { всегда полноводна как море. }\end{array}$ \\
\hline (85) & $\begin{array}{l}\text { čing sayin erdemtei kümün } \\
\text { činō xoni xoyori nigen ongrocōdu } \\
u=\text { sulxu:: }\end{array}$ & (108) & $\begin{array}{l}\text { Умный и находчивый человек, } \\
\text { Сумеет напоить из одного корыта волка и } \\
\text { овцу. }\end{array}$ \\
\hline (86) & 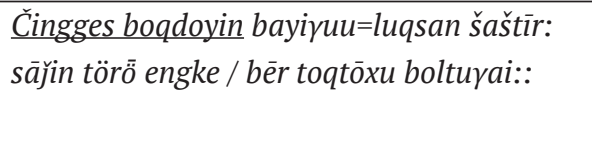 & (108) & $\begin{array}{l}\text { Благодаря шастре, созданной сиятельным } \\
\text { Чингис-ханом, } \\
\text { Да утвердится навечно государство! }\end{array}$ \\
\hline (87) & 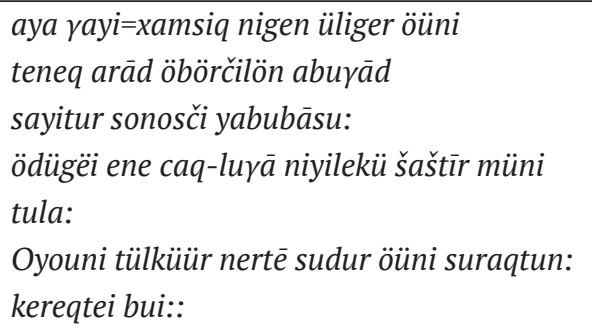 & (109) & $\begin{array}{l}\text { Ая, если эти удивительные наставления, } \\
\text { глупый народ усвоит для себя и будет истинно } \\
\text { следовать им, } \\
\text { Поскольку она созвучна этому времени, } \\
\text { Постигайте эту шастру под названием «Ключ } \\
\text { разума». } \\
\text { Это необходимо! }\end{array}$ \\
\hline
\end{tabular}

\section{СПИСОК ЛИТЕРАТУРЫ}

Бадмин, А. (1991) Тод үзгин «Оюн түлкүрин» хойр текст [Два текста «Ключа разума» на «ясном» (старокалмыцком) письме] // Теегин Герл. № 6. С. 64-75. (На калм. яз.).

Бембеев, Е. В. (2014) Графо-фонетический анализ гласных на материале «Русско-калмыцкого словаря анонимного автора XVIII в.» // Актуальные проблемы современного монголоведения и алтаистики. Материалы Международной научной конференции, посвященной 75- летию со дня рождения и 55-летию научно-педагогической деятельности профессора В. И. Рассадина (г. Элиста, 10-13 ноября 2014 г.) / отв. ред. Б. К. Салаев. Элиста: Изд-во КалмГУ. 523 с. С. 204-210.

Бичеев, Б. А. (2018) Ойратская версия «Истории Унэкэр Торликту-хана». Факсимиле рукописей. Исследование, транслитерация, перевод с ойратского, комментарии Б. А. Бичеева. Элиста : КалмНЦ РАН. 384 c.

Бичеев, Б. А. (2019) Списки рукописей и история публикации «Истории Усун Дебискерту-хана» // Oriental Studies. Вып. 3. С. 441-449. DOI: 10.22162/2619-0990-2019-43-3-441- 449

Владимирцов, Б. Я. (1932) Монгольские литературные языки (К латинизации монгольской и калмыцкой письменности) // Записки Института востоковедения АН СССР. І. Л.: Изд-во Академии наук СССР. 321 c. С. $1-18$.

Козин, С. А. (1941) Сокровенное сказание. Монгольская хроника 1240 г. М.-Л.: Изд. АН СССР. 619 с.

Михайлов, Г. И. (1969) Литературное наследство монголов. М.: Наука. 174 с. 
Подгорбунский, И. А. (1901) Буддизм, его история и основные положения его учения. Вып. 1-2. Иркутск: Тип. А. А. Сизых. Т. 2. 242 с. (Труды Восточно-Сибирского отдела Имп. Русского географического общества).

Позднеев, А. М. (1900) Монгольская хрестоматия для первоначального преподавания. Издания факультета восточных языков Имп. С.-Петербургского университета № 7. СПб. : Типография Императорской академии наук. 416 с.

Попов, А. (1836) Монгольская хрестоматия для начинающих обучаться монгольскому языку, изданная Казанского университета адъюнкт-профессором Александром Поповым. Казань : Тип. Имп. Казан. ун-та. Ч. 1.199 с.

Рамстедт, Г. И. (1908) Сравнительная фонетика монгольского письменного языка и халхаско-ургинского говора. СПб. : Типография Императорской академии наук. 66 с.

Сазыкин,А.Г. (1986) Монгольские рукописи и ксилографы, поступившие в Азиатский музей Российской академии наук от Б. Я. Владимирцова // Mongolica-I. Памяти академика Б. Я. Владимирцова (1884-1931). М. : Наука. Восточная литература. 303 с. С. 265-297.

Сазыкин, А. Г. (1988) Каталог монгольских рукописей и ксилографов Института Востоковедения АН СССР. М.: Наука. Восточная литература. Т. І. 507 с.

Сазыкин, А. Г. (1992) Собрание монгольских рукописей и ксилографов из фондов Тувинского республиканского краеведческого музея им. 60 богатырей (Кызыл) // Тюркские и монгольские письменные памятники. Текстологические и культуроведческие аспекты исследования: сборник статей / отв. ред. С. Г. Кляшторный и Ю. А. Петросян. М. : Наука. Восточная литература. 162 с. С. 45-58.

Яхонтова, Н. С. (1992) Ойратский перевод монгольского сочинения «Ключ разума» // Тюркские и монгольские письменные памятники. Текстологические и культуроведческие аспекты исследования : сборник статей / отв. ред. С. Г. Кляшторный и Ю. А. Петросян. М.: Наука. Восточная литература. 162 с. C. $137-152$.

Яхонтова, Н. С. (2001) «Ключ разума» (ойратский текст) // Mongolica-V: сборник статей / отв. ред. С. Г. Кляшторный. СПб.: Петербургское востоковедение. 184 с. С. 38-53.

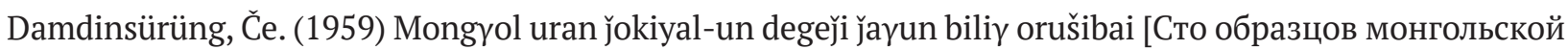
литературы]. Corpus scriptorum mongolorum, Tomus XIV. Ulayanbayatur. 605 x.

Gerelmaa, G. (2005) Brief Catalogy of Oirat Manuscripts Kept by Institute of Language and Literature bu Gerelmaa Guruuchin. Ulaanbaatar : XЗХ ШУА. 270 p.

Sazykin, A. (1994) Catalogue of the Mongol manuscripts and xylographs preserved in the library of the Tuvan Ethnological museum "Sixty Heroes" // Acta Orientalia Academiae Scientarium Hungaricae. Tomus XLVII, Fas. 3. Budapest : Academiai Kiado. 467 p. Pp. 327-407.

Тунгалаг, Б. (2006) Монгол улсын үндэсний номын сан дахь тод бичгийн судрын гарчиг. Улаанбаатар : Тайм принтинг ХГ. 277 с.

Uspensky, V. (1999) Catalogue of the Mongolian Manuscripts and Xylographs in the St. Petersburg State University Library. Tokyo : Institute for the Study of Languages and Cultures of Asia and Africa. 530 p.

Yakhontova, N. (2000) The Oyun Tülkigür oe "Key to Wisdom": Text and Translation Based on The MSS in the Institute for Oriental Studies at St. Petersburg // Mongolian Studies. XXIII. 170 p. P. 69-137.

Дата поступления: 01.06.2019 г.

\section{REFERENCES}

Badmin, A. (1991) Tod üzgin «Oiun tülkürin» khoir tekst [Two texts of the "Key to Wisdom" in the "clear writing” (Old Kalmyk)]. Teegin Gerl, no. 6, pp. 64-75. (In Kalm.).

Bembeev, E. V. (2014) Grafo-foneticheskii analiz glasnykh na materiale «Russko-kalmytskogo slovaria anonimnogo avtora XVIII v.» [A graphical and phonetic analysis of vowels on the material of the "RussianKalmyk dictionary of an anonymous author of the XVIII century"]. In: Aktual'nye problemy sovremennogo mongolovedeniia i altaistiki [Urgent issues of contemporary Mongolian and Altaistic studies]. Materials of an international conference devoted to 75th anniversary of the birth and the 55th anniversary of research and educational work of Professor V. I. Rassadin (10-13.11.2014, Elista, Rossiia). Ed. by B. K. Salaev. Elista, Kalmyk State University Publ. 523 p. Pp. 204-210. (In Russ.). 
Bicheev, B. A. (2018) Oiratskaia versiia «Istorii Uneker Torliktu-khana» [The Oirat version of the story of Uneker Torliktu Khan]: A facsimile manuscript copy. Study, transliteration, translation from Oirat, and comments by B. A. Bicheev. Elista, KalmNC RAN. 384 p. (In Russ.).

Bicheev, B. (2019) Spiski rukopisej i istoriya publikacii «Istorii Usun Debiskertu-hana» ['The Story of Usun Debiskertu Khan': Manuscript Copies and History of Publication]. Oriental Studies, issue 3, pp. 441-449. DOI: 10.22162/2619-0990-2019-43-3-441-449 (In Russ.).

Vladimirtsov, B. Ia. (1932) Mongol'skie literaturnye iazyki (K latinizatsii mongol'skoi i kalmytskoi pis'mennosti) [Mongolian literary languages (On the romanization of the Mongolian and Kalmyk script)]. In: Zapiski Instituta vostokovedeniia AN SSSR. Issue I. Leningrad, AN SSSR Publ. 321 p. Pp. 1-18. (In Russ.).

Kozin, S. A. (1941) Sokrovennoe skazanie. Mongol'skaia khronika 1240 g. [The Secret History: Mongolian Chronicle of 1240]. Moscow, Leningrad, AN SSSR Publ. 619 p. (In Russ.).

Mikhailov, G. I. (1969) Literaturnoe nasledstvo mongolov [The Mongolian literary heritage]. Moscow, Nauka Publ. 174 p. (In Russ.).

Podgorbunskii, I. A. (1901) Buddizm, ego istoriia i osnovnye polozheniia ego ucheniia [Buddhism, its history and the main provisions of his teachings]. Issue 1-2. / Trudy Vostochno-Sibirskogo otdela Imp. Russkogo geograficheskogo obshchestva. Irkutsk, Type. A. A. Sizykh, 1901.Vol. 2. 242 p. (In Russ.).

Pozdneev, A. M. (1900) Mongol'skaia khrestomatiia dlia pervonachal'nogo prepodavaniia [Mongolian anthology for the introductory course] / Izdaniia fakul'teta vostochnykh iazykov Imp. S.-Peterburgskogo universiteta № 7. St. Petersburg. Tipografiia Imperatorskoi akademii nauk. 416 p. (In Russ.).

Popov, A. (1836) Mongol'skaia khrestomatiia dlia nachinaiushchikh obuchat'sia mongol'skomu iazyku, izdannaia Kazanskogo universiteta ad'iunkt-professorom Aleksandrom Popovym [Mongolian anthology for those beginning the study of the Mongolian language, published by Alexander Popov, Adjunct Professor of Kazan University]. Part 1. Kazan'. Tip. Imp. Kazan. un-ta. 199 p. (In Russ.).

Ramstedt, G. I. (1908) Sravnitel'naia fonetika mongol'skogo pis'mennogo iazyka i khalkhasko-urginskogo govora [Comparative phonetics of the Mongolian written language and Khalkha-Urgin dialect]. St. Petersburg, Tipografiia Imperatorskoi akademii nauk. 66 p. (In Russ.).

Sazykin, A. G. (1986) Mongol'skie rukopisi i ksilografy, postupivshie v Aziatskii muzei Rossiiskoi akademii nauk ot B. Ia. Vladimirtsova [Mongolian manuscripts and woodcuts, obtained by the Asiatic Museum of the Russian Academy of Sciences from B. Ya. Vladimirtsov]. In: Mongolica-I. In memory of academician B. Ya. Vladimirtsov (1884-1931). Moscow, Nauka Publ. 303 p. Pp. 265-297. (In Russ.).

Sazykin, A. G. (1988) Katalog mongol'skikh rukopisei i ksilografov Instituta Vostokovedeniia AN SSSR [Catalog of Mongolian manuscripts and woodcuts of the Institute of Oriental Studies of the USSR Academy of Sciences]. Moscow, Nauka Publ. Vol. I. 507 s. (In Russ.).

Sazykin, A. G. (1992) Sobranie mongol'skikh rukopisei i ksilografov iz fondov Tuvinskogo respublikanskogo kraevedcheskogo muzeia im. 60 bogatyrei (Kyzyl) [A collection of the Mongol manuscripts and xylographs preserved in the funds of the Aldan-Maadyr National Museum of Tuva (Kyzyl)]. In: Tiurkskie $i$ mongol'skie pis'mennye pamiatniki. Tekstologicheskie i kul'turovedcheskie aspekty issledovaniia [Turkic and Mongolian written monuments: Textual and cultural aspects]: a collection of papers. Moscow, Nauka, Vostochnaia literatura Publ. 162 p. Pp. 45-58. (In Russ.).

Iakhontova, N. S. (1992) Oiratskii perevod mongol'skogo sochineniia «Kliuch razuma» [Oirat translation of the Mongol text of the "Key to Wisdom"]. In: Tiurkskie i mongol'skie pis'mennye pamiatniki. Tekstologicheskie i kul'turovedcheskie aspekty issledovaniia [Turkic and Mongolian written monuments: Textual and cultural aspects]: a collection of papers. Moscow, Nauka, Vostochnaia literatura Publ. 162 p. Pp. 137-152. (In Russ.).

Iakhontova, N. S. (2001) «Kliuch razuma» (oiratskii tekst) [“Key to Wisdom” (The Oirat text)]. In: MongolicaV: a collection of papers. St. Petersburg, Peterburgskoe vostokovedenie Publ. 184 p. Pp. 38-53. (In Russ.).

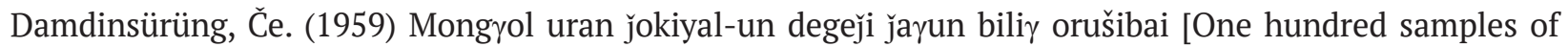
Mongolian literature]. Corpus scriptorum mongolorum, Tomus XIV. Ulayanbayatur. 605 p. (In Mong.).

Gerelmaa, G. (2005) Brief Catalogy of Oirat Manuscripts Kept by Institute of Language and Literature bu Gerelmaa Guruuchin. Ulaanbaatar, ILL MAS. 270 p. (In Mong.).

Sazykin, A. (1994) Catalogue of the Mongol manuscripts and xylographs preserved in the library of the Tuvan Ethnological museum “Sixty Heroes”. Acta Orientalia Academiae Scientarium Hungaricae, vol. XLVII, Fas. 3. Budapest, Academiai Kiado. 467 p. Pp. 327-407. (In Eng.). 
Tungalag, B. (2006) Mongol ulsyn ündesnii nomyn san dakh' tod bichgiin sudryn garchig. Ulaanbaatar, Taim printing KhG. 277 p. (In Mong.).

Uspensky, V. (1999) Catalogue of the Mongolian Manuscripts and Xylographs in the St. Petersburg State University Library. Tokyo, Institute for the Study of Languages and Cultures of Asia and Africa. $530 \mathrm{p}$.

Yakhontova, N. (2000) The Oyun Tülkigür or "Key to Wisdom": Text and Translation Based on The MSS in the Institute for Oriental Studies at St. Petersburg. Mongolian Studies XXIII. 170 p. Pp. 69-137.

Submission date: 01.06.2019. 